\title{
Diurnal variability and biogeochemical reactivity of mercury species in an extreme high-altitude lake ecosystem of the Bolivian Altiplano
}

\author{
L. Alanoca ${ }^{1} \&$ D. Amouroux ${ }^{1,2} \& M$. Monperrus ${ }^{2} \&$ E. Tessier ${ }^{2} \& M$. Goni $^{3} \&$

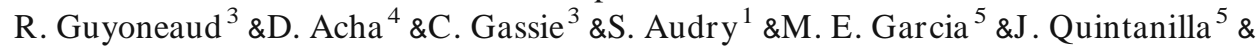 \\ D. Point ${ }^{1,4}$
}

Received: 19 August 2015 / Accepted: 2 December 2015 /Published online: 17 December 2015

\# Springer-Verlag Berlin Heidelberg 2015

Abstract Methylation and demethylation represent major transformation pathways regulating the net production of methylmercury (MMHg). Very few studies have documented $\mathrm{Hg}$ reactivity and transformation in extreme high-altitude lake ecosystems. Mercury $(\mathrm{Hg})$ species concentrations $(\mathrm{IHg}$, $\mathrm{MMHg}, \mathrm{Hg}^{\circ}$, and $\mathrm{DMHg}$ ) and in situ $\mathrm{Hg}$ methylation (M) and MMHg demethylation (D) potentials were determined in water, sediment, floating organic aggregates, and periphyton compartments of a shallow productive Lake of the Bolivian Altiplano (Uru Uru Lake, 3686 m). Samples were collected during late dry season (October 2010) and late wet season

Responsible editor: Philippe Garrigues

Electronic supplementary material The online version of this article (doi:10.1007/s11356-015-5917-1) contains supplementary material, which is available to authorized users.

* D. Amouroux

david.amouroux@univ-pau.fr

1 Géosciences Environnement Toulouse, UMR 5563-IRD UR 234, Université Paul Sabatier, 14 Avenue Edouard Belin, 31400 Toulouse, France

2 Laboratoire de Chimie Analytique Bio-inorganique et Environnement, IPREM UMR 5254 CNRS, Université de Pau et des Pays de l' Adour, Hélioparc Pau Pyrénées, 2, av. P. Angot, 64053 Pau cedex 9, France

3 Equipe Environnement et Microbiologie, IPREM UMR 5254 CNRS, Université de Pau et des Pays de l'Adour, Bâtiment IBEAS, BP1153, 64013 Pau Cedex, France

4 Laboratorio de Calidad Ambiental, Instituto de Ecologia, Universidad Mayor de San Andres, Campus Universitario de Cota Cota, casilla 3161, La Paz, Bolivia

5 Laboratorio de Hidroquímica, Instituto de Investigaciones Químicas, Universidad Mayor de San Andres, Campus Universitario de Cota Cota, casilla 3161, La Paz, Bolivia
(May 2011) at a north (NS) and a south (SS) site of the lake, respectively. Mercury species concentrations exhibited significant diurnal variability as influenced by the strong diurnal biogeochemical gradients. Particularly high methylated mercury concentrations $\left(0.2\right.$ to $4.5 \mathrm{ng} \mathrm{L} \mathrm{L}^{-1}$ for $\mathrm{MMHg}_{\mathrm{T}}$ ) were determined in the water column evidencing important $\mathrm{Hg}$ methylation in this ecosystem. Methylation and D potentials range were, respectively, $<0.1-16.5$ and $<0.2-68.3 \%$ day $^{-1}$ and were highly variable among compartments of the lake, but always higher during the dry season. Net $\mathrm{Hg} \mathrm{M}$ indicates that the influence of urban and mining effluent (NS) promotes $\mathrm{MMHg}$ production in both water (up to $0.45 \mathrm{ng}$ MMHg L ${ }^{-1}$ day $^{-1}$ ) and sediment compartments (2.0 to $19.7 \mathrm{ng} \mathrm{MMHg} \mathrm{g}^{-1} \mathrm{day}^{-1}$ ). While the sediment compartment appears to represent a major source of MMHg in this shallow ecosystem, floating organic aggregates (dry season, SS) and Totora's periphyton (wet season, NS) were found to act as a significant source $\left(5.8 \mathrm{ng} \mathrm{MMHg} \mathrm{g}{ }^{-1} \mathrm{day}^{-1}\right.$ ) and a sink $\left(-2.1 \mathrm{ng} \mathrm{MMHg} \mathrm{g}{ }^{-1} \mathrm{day}^{-1}\right)$ of $\mathrm{MMHg}$, respectively. This work demonstrates that high-altitude productive lake ecosystems can promote $\mathrm{MMHg}$ formation in various compartments supporting recent observations of high $\mathrm{Hg}$ contents in fish and water birds.

Keywords Mercury $\cdot$ Biogeochemistry $\cdot$ Altiplano $\cdot$ Lake $\cdot$ Methylation $\cdot$ Demethylation $\cdot$ Bolivia

\section{Introduction}

Methylmercury (MMHg) is considered as a potent neurotoxin and represents a significant health concern (Allen et al. 2002). Human MMHg exposure is mainly controlled by the consumption of fish products (Fitzgerald and Clarkson 1991; 
UNEP 2013). MMHg can be produced in different compartments of the aquatic ecosystem as influenced by biogeochemical conditions (Fitzgerald and Lamborg 2004; Hintelmann 2010). In aquatic ecosystems, $\mathrm{Hg}$ methylation may take place in the anoxic zone (Eckley and Hintelmann 2006) or oxic zone (Bouchet et al. 2013; Monperrus et al. 2007; Ribeiro Guevara et al. 2008), in the first few centimeters of sediments (Bouchet et al. 2013; Hollweg et al. 2009) and in the periphyton mainly associated with the roots of aquatic plants (Gentès et al. 2013; Guimarães et al. 2000). The mechanisms of mercury methylation (M) mainly involve microbial processes linked to the activities of various communities such as sulfate- and/or iron-reducing bacteria (Barkay and Wagner-Döbler 2005; Compeau and Bartha 1984) and, to a lesser extent, abiotic processes (Craig and Morton 1978; Weber 1993). Overall, net production rates of $\mathrm{MMHg}$, and its bioaccumulation in the food chain of aquatic systems, is drastically regulated by such transformation processes (Hintelmann 2010).

Mediated by biotic and abiotic processes, MMHg may be methylated and form dimethylmercury (DMHg) (Baldi et al. 1995), and/or broken down or demethylated (D), giving rise to inorganic $\mathrm{Hg}$ and elemental mercury $\left(\mathrm{Hg}^{\circ}\right)$. In sediments, the methylation process involves sulfate- and nitrate-reducing bacteria as well as methanogenic bacteria, along oxidative or reductive pathways (Oremland et al. 1991; Schaefer et al. 2004; Spangler et al. 1973). In the water column, most of MMHg demethylation likely originates from photodegradation reactions (Black et al. 2012; Hammerschmidt and Fitzgerald 2006; Sellers et al. 1996).

Because of its importance for human health, $\mathrm{Hg}$ cycling has been studied in different aquatic systems (oceans, lakes, lagoons, rivers, and wetlands). $\mathrm{Hg}$ reactivity and transformation in lake and wetland ecosystems is well documented (Hintelmann 2010), but few studies have investigated $\mathrm{Hg}$ reactivity in extreme high-altitude ecosystems (Marusczak et al. 2011; Qianggong et al. 2014; Ribeiro Guevara et al. 2008). Aquatic ecosystems located in the South American Altiplano region at $3800 \mathrm{~m}$ exhibit extreme thermal and solar irradiance diurnal variability including intense UV radiations (Blumthaler et al. 1997; Zaratti et al. 2003), contrasted seasonal hydrological cycles, as well as intense primary production (Aguirre et al. 2014). Lake Uru Uru (3686 m a.s.1.) is part of the lake system occupying the central Bolivian Altiplano region. This lake ecosystem acts as a sink for several mining and urban waste effluents (Garcia 2006; Tapia et al. 2012), while it hosts numerous endemic avian and fish species and has social and economic importance for the region's indigenous population, who live from hunting and fishing (Aguirre et al. 2014; Garcia 2006). Elevated Hg levels were documented in different species of water birds and fish from Lake Uru Uru (Aguirre et al. 2014; Molina et al. 2012)

This work aims at documenting for the first time $\mathrm{Hg}$ biogeochemistry and $\mathrm{Hg}$ methylation capacity in the case of high- altitude tropical productive lakes, using Lake Uru Uru as a reference study site. In this lake, a contaminated northern (NS) and a less impacted southern (SS) site were carefully investigated on a diurnal and seasonal basis with the measurement of different $\mathrm{Hg}$ compounds ( $\mathrm{IHg}, \mathrm{MMHg}, \mathrm{Hg}^{\circ}$, and $\mathrm{DMHg}$ ) and the complementary determination of in situ $\mathrm{Hg}$ methylation (M) and MMHg demethylation (D) potentials in water, sediment, floating organic aggregates, and periphyton compartments collected from Totora's (Schoenoplectus californicus) aquatic plants.

\section{Materials and methods}

Study area

Lake Uru Uru is a shallow aquatic system ( $1.5 \mathrm{~m}$ av. depth) located at $3686 \mathrm{~m}$ above sea level in the central part of the Bolivian Altiplano region, in South America (Fig. 1). Lake Uru Uru is located downstream of Lake Titicaca and upstream of Lake Poopó and is part of the closed, evaporative endorheic Titicaca-Desaguadero-Poopo-salar (TDPS) basin. During the wet season, Lake Uru Uru displays a surface area of $350 \mathrm{~km}^{2}$, reduced to $120 \mathrm{~km}^{2}$ during the dry season. Further details on the study area are provided in the Supplementary Material (SM) section.

\section{Samples collection and processing}

Samples of sediment, surface waters, and organic substrates were collected from Lake Uru Uru at two different sites (Fig. 1). The first site (NS) located in the northern part of the lake represents a contaminated site, under the influence of both mining and urban effluents originating from the mining city of Oruro (Fig. 1). The second site (SS) is located in the southern part of the lake and is supposed to represent a less polluted area, although lateral inputs of mining effluent from Rio Huanuni may be considered. All samples were taken at the end of the dry season (October 2010) and at the end of the wet season (May 2011), respectively, for investigating seasonal differences. Diurnal cycles ( $24 \mathrm{~h}$ ) were also investigated in the water column at the two stations at a 4-h resolution step at the NS site (only for wet season) and at a 2-h resolution step at the SS site (both seasons). Because both NS and SS sites are very shallow $(<1 \mathrm{~m})$ and present a well-mixed water column, water sample was directly hand-collected from a rubber boat at the subsurface (ca. 10-30 cm depth, depending on the seasonal water level). Each water sample was divided into three aliquots, two of them subsequently acidified: one was filtered (Bdissolved fraction ${ }^{\wedge}$ ) using a vacuum filtration pump and 0.45- $\mathrm{m}$ m porosity PVDF filters (Millipore, Bedford, MA, USA), while the second was kept unfiltered (total content). A last aliquot was kept intact and directly processed to purge 


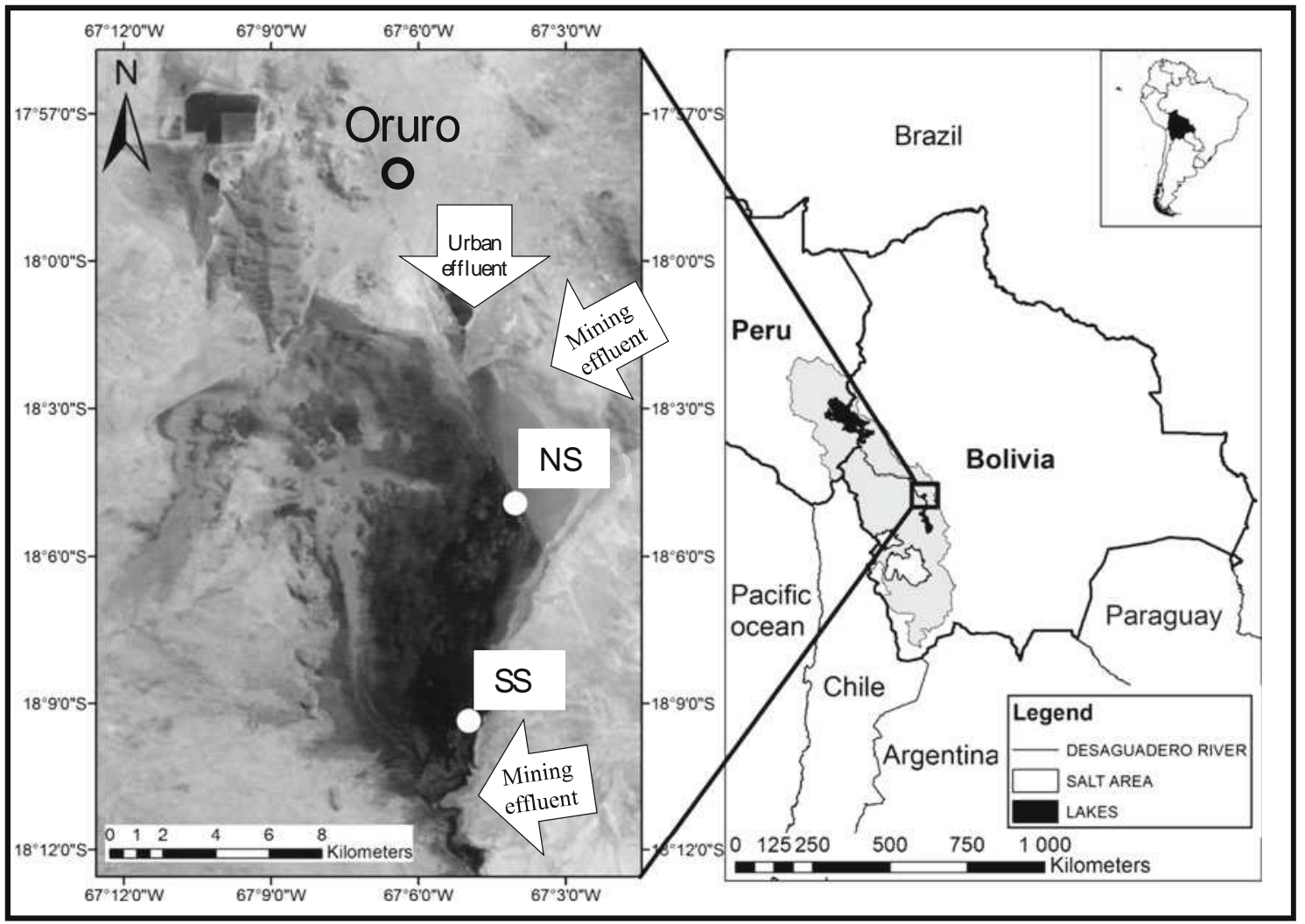

Fig. 1 Map of Lake Uru Uru and its location in the Bolivian Altiplano (Bolivia, South America), showing the investigated sites in the northern (NS) and southern (SS) part of the lake, during late dry and wet seasons
(October 2010 and May 2011). The major sources of contamination are also indicated: urban effluent (north) and mining effluent (south) and trap the gaseous $\mathrm{Hg}$ compounds (i.e., DGM, DMHg). Further details for surface sediments $(0-1 \mathrm{~cm})$ and bioorganic substrates (periphyton, aggregates) sampling are given in the SM section. For comparison with other lacustrine environments of the TDPS hydrosystem, sediment samples were also taken from Lake Titicaca during the dry season and from Lake Poopó during the wet season. Further details on sample processing and ancillary parameters determination are included in the SM section.

\section{Mercury transformations assays}

Mercury species transformation potentials were determined through in situ incubations performed using isotopically enriched mercury species $\left({ }^{199} \mathrm{HgCl}_{2}\right.$ and $\left.\mathrm{CH}_{3}{ }^{201} \mathrm{HgCl}\right)$ for water, sediment, periphyton, and floating organic aggregates, according to the incubation protocol, analyses, and calculations of methylation (M), demethylation (D), and reduction (R) potentials described elsewhere (Monperrus et al. 2007; Rodriguez-Gonzalez et al. 2013). This methodology allows the simultaneous and quantitative determination of newly formed and remaining $\mathrm{Hg}$ species derived from each isotope, and the determination of specific formation/degradation yields (Monperrus et al. 2007; Rodriguez-Gonzalez et al. 2013).
Further details on the incubation protocols and the evaluation of the net mercury methylation obtained from the incubation experiments and diurnal cycles are described in the SM section.

\section{Samples analysis methodologies}

For water samples, the concentrations of total and dissolved $\mathrm{Hg}$ species, such as $\mathrm{MMHg}, \mathrm{IHg}, \mathrm{Hg}^{\circ}$, and DMHg were determined. For solid samples, concentration of $\mathrm{MMHg}$ and $\mathrm{IHg}$ was determined. $\mathrm{Hg}$ species analysis in water, sediment, and biological substrates was performed by capillary gas chromatography connected to an inductively coupled plasma mass spectrometer (GC-ICPMS, Trace). Analytical set-up and methodology for the GC-ICPMS for $\mathrm{Hg}$ speciation analysis are described in detail elsewhere (Monperrus et al. 2008; Monperrus et al. 2005). The analysis of the gaseous $\mathrm{Hg}$ species (i.e., $\mathrm{Hg}^{\circ}$ and $\mathrm{DMHg}$ ) was carried out by cryogenic trapping gas chromatography connected to an inductively coupled plasma mass spectrometer (CT-GC-ICPMS) according to previous works (Bouchet et al. 2013; Bouchet et al. 2011). Other analytical methods used for ancillary parameters are described in SM section. 
Bacterial community characterization

Water samples (triplicates) were concentrated $(250 \mathrm{~mL}$ for $\mathrm{SS}$ and $60 \mathrm{~mL}$ for $\mathrm{NS}$ ) by filtration on sterile cellulose acetate filters (Millipore, $0.22 \mu \mathrm{m}$ ). After filtration, the filters were immediately frozen in liquid nitrogen. Samples from sediments, floating aggregates, or Totora's biofilms were directly sampled in cryovials and frozen in liquid nitrogen. DNA was extracted with the Ultra Clean Soil DNA Isolation Kit using the alternative lysis method (MoBio Laboratories Inc., USA). All extracted genomic DNA samples were stored at $-20{ }^{\circ} \mathrm{C}$ until further processing. T-RFLP was performed as previously used by Gentès et al. (2013). T-RFLP profiles were compared by principal component analysis (PCA) using MVSP v3.13d software (Rockware Inc., UK).
Fig. 2 a-h Diurnal variability (24 h) of the different $\mathrm{Hg}$ species $\left(\mathrm{IHg}_{\mathrm{T}}, \mathrm{IHg}_{\mathrm{d}}, \mathrm{MMHg}_{\mathrm{T}}, \mathrm{MMHg}_{\mathrm{d}}\right.$, $\mathrm{Hg}^{\circ}, \mathrm{DMHg}$ ) in comparison with oxygen and temperature at the southern site (SS) of Lake Uru Uru for late dry and wet seasons. $\mathrm{T}$ total, $\mathrm{d}$ dissolved (a)

\section{Dry season}

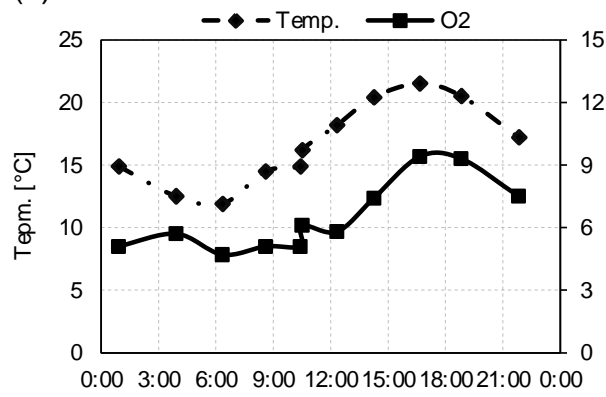

(c)

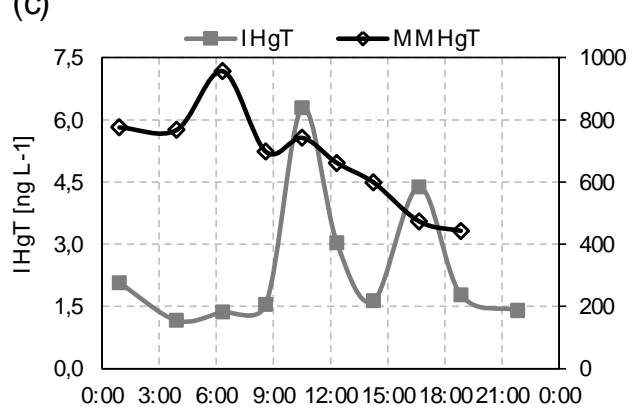

(e)

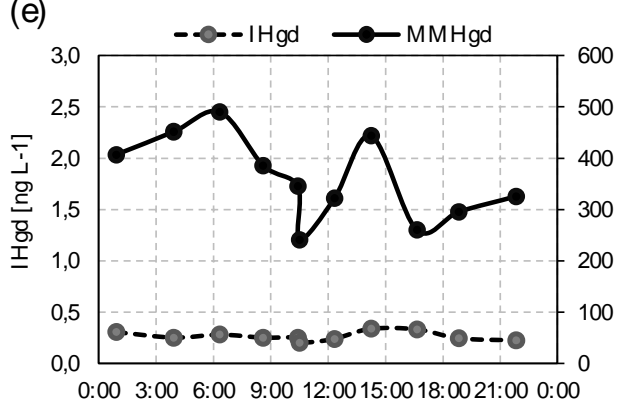

(g)

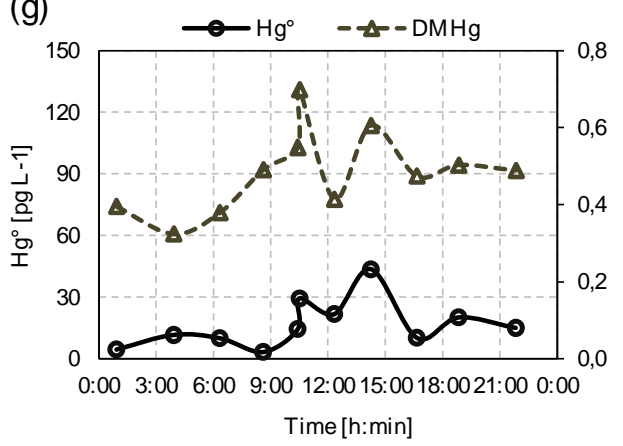

Wet season

(b)

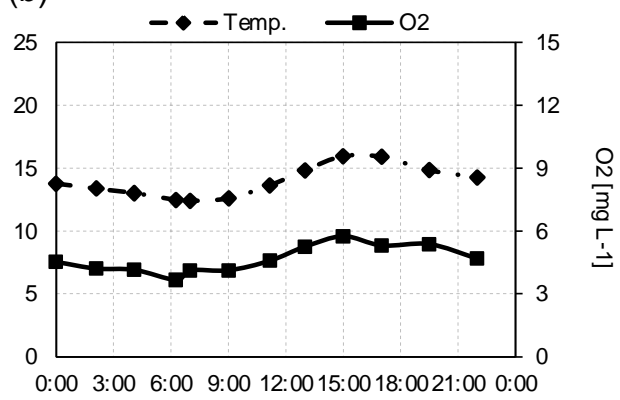

(d)

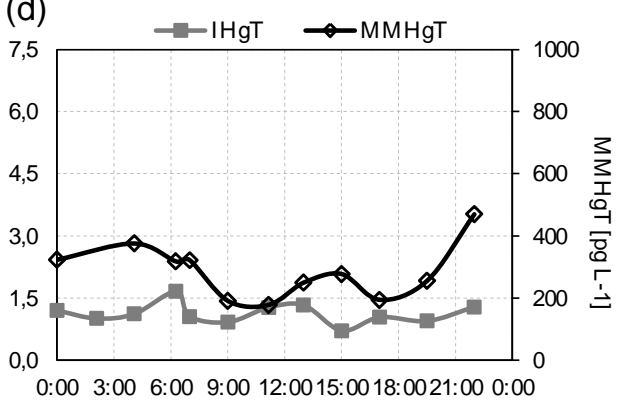

(f)

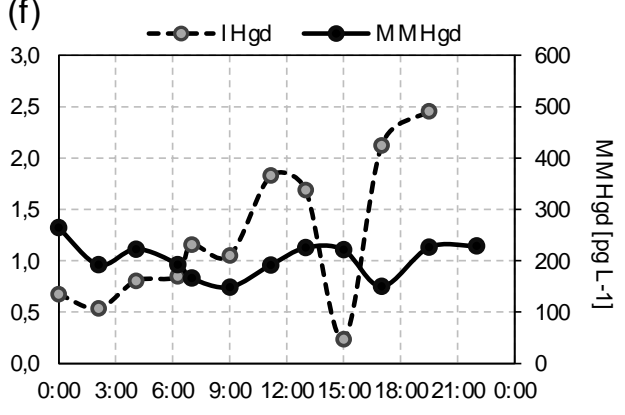

(h)

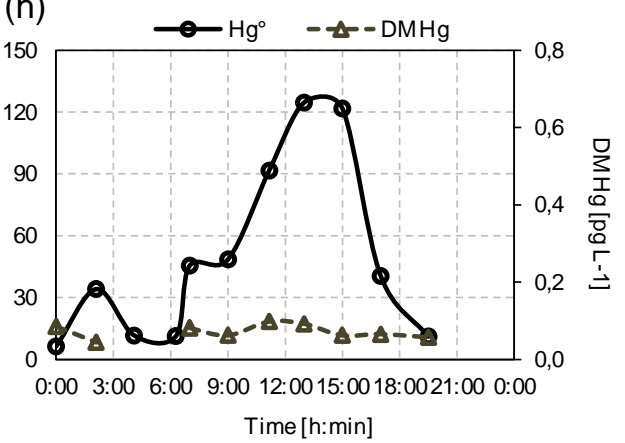




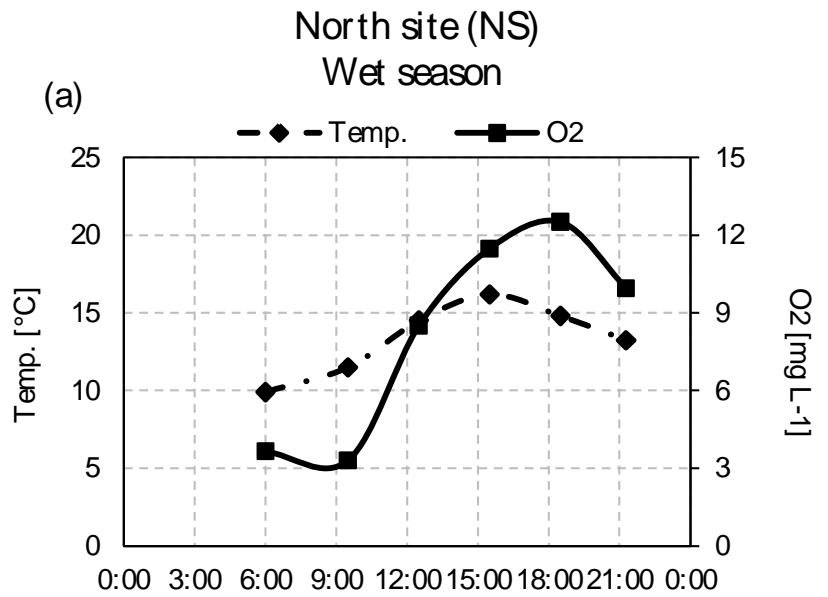

(b)
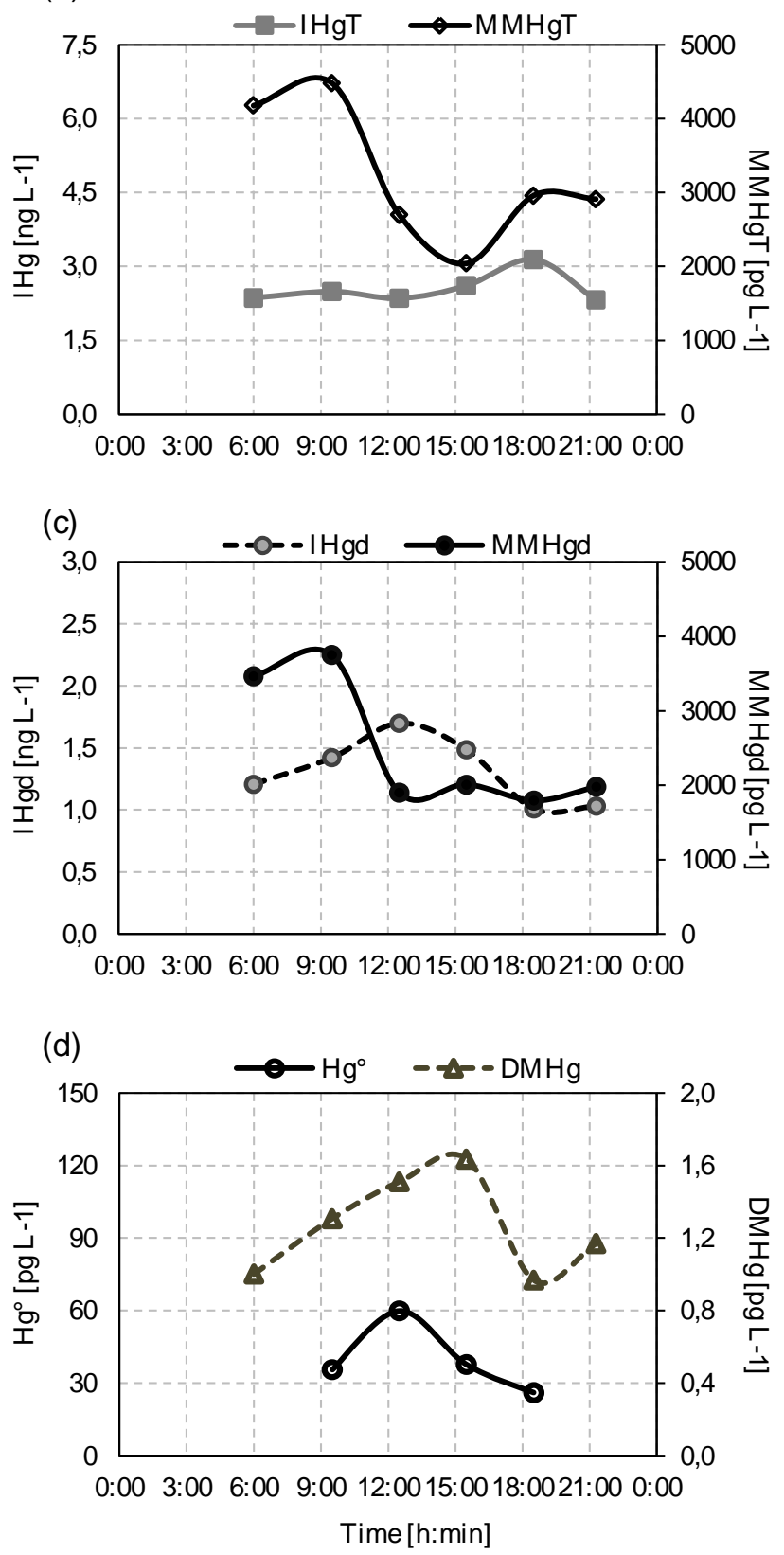

\section{Statistics}

For dataset comparison, statistical parametric test (Student $\mathrm{t}$ test) for normal data distribution and non-parametric test (Kruskal-Wallis test) for non-normal data distribution were considered, using SigmaStat (version 3.0.) or R software (R.2.14.2).

\section{Results and discussion}

Major biogeochemical characteristics

High-resolution diurnal profiles of selected parameters are displayed in Fig. 2 (data summary in Table A, SM). At the SS site, relative different trends can be observed during the diurnal cycles and between the dry and wet seasons. Mean diurnal temperature and oxygen concentrations were higher during the dry season compared to the wet season but not statistically different $\left(16.3\right.$ and $13.9^{\circ} \mathrm{C}, 6.5$ and $4.6 \mathrm{mg} \mathrm{L}^{-1}$, respectively), while $\mathrm{pH}$ values were relatively close ( 7.9 and 8.1). However, their diurnal gradient amplitude between sunrise and sunset (Fig. 2) was much higher during the dry season (11.9-21.5 and $12.4-16.0^{\circ} \mathrm{C}, 7.0-8.2$ and 7.8-8.4, 4.7-9.4 and $3.7-5.8 \mathrm{mg} \mathrm{L}^{-1}$, respectively). This reflects the change in solar radiations intensity among seasons. Solar radiation levels measured close to the study site in Patacamaya (Oruro Dpt, Bolivia) from September to November 2010 (dry season) and from April to June 2011 (wet season) were, respectively, $313.8 \pm 55.4$ and $243.5 \pm 36.2 \mathrm{~W} \mathrm{~m}^{-2}$. Conductivity at the SS varied significantly (s test, $\mathrm{p}<0.05$ ) between dry $\left(6.2 \mathrm{mS} \mathrm{cm} \mathrm{cm}^{-1}\right)$ and wet $\left.(3.1 \mathrm{mS} \mathrm{cm})^{-1}\right)$ seasons due to the intense evaporation process, while at the NS diurnal variations during the wet season, exhibited wider ranges for temperature, $\mathrm{pH}$, and oxygen than at SS $\left(9.9-16.2{ }^{\circ} \mathrm{C}, 9.2-10.1\right.$ and 3.3$12.5 \mathrm{mg} \mathrm{L}^{-1}$, respectively). Conductivity was higher at the NS site $\left(8.8 \mathrm{mS} \mathrm{cm}^{-1}\right)$ compared to $\mathrm{SS}$ site $\left(3.1 \mathrm{mS} \mathrm{cm}^{-1}\right)$ during the wet season. Since bacterial activity is one of the main driver responsible for mercury methylation and demethylation, strong daily variations of temperature, $\mathrm{pH}$, and oxygen may strongly affect diurnal $\mathrm{Hg}$ cycle at short timescale. While not measured over $24 \mathrm{~h}$, dissolved organic carbon (DOC), particulate organic carbon (POC), and suspended particulate matter (SPM) may influence significantly mercury speciation. For instance, DOC concentrations reach high values for both seasons at SS and NS station (14.4-16.4 and 19.8$24.5 \mathrm{mg} \mathrm{L}^{-1}$, respectively), while SPM remains rather low $\left(<10 \mathrm{mg} \mathrm{L}^{-1}\right)$ but enriched in organic carbon (10\% of POC).

${ }^{E ⿰}$ Fig. 3 a-d Diurnal variability (24 h) of the different $\mathrm{Hg}$ species $\left(\mathrm{IHg}_{\mathrm{T}}\right.$, $\mathrm{IHg}_{\mathrm{d}}, \mathrm{MMHg}_{\mathrm{T}}, \mathrm{MMHg}_{\mathrm{d}}, \mathrm{Hg}^{\circ}, \mathrm{DMHg}$ ) in comparison with oxygen and temperature at the northern site (NS) of Lake Uru Uru for the late wet season. $\mathrm{T}$ total, $\mathrm{d}$ dissolved 
Sulfate-reducing bacteria communities

The T-RFLP based on dsr genes polymorphism, applied to detect sulfate-reducing bacteria, indicated that they were present in all the samples collected at NS and SS in Lake Uru Uru. During the dry season, the composition of sulfate-reducing bacterial communities in sediments and bio-organic aggregates was homogeneous (Fig. 4), but very heterogeneous in water samples. Similar results were obtained in the water samples during the wet season (data not shown). This heterogeneity is probably due to the occurrence in different proportion of particulate material and also to the lower abundances in dsr $\mathrm{AB}$ genes. The correspondence analysis shows a strong effect of the reducing conditions (sediments vs water) on the samples' dsrAB diversity as distributed along the axis 1 (32\% of the variance). It also highlights the influence of available organic carbon (water vs bio-organic aggregates) through the axis 2, explaining $30 \%$ of the sulfate-reducing bacteria community composition.

$\mathrm{Hg}$ species distribution and transformation in the water column

Mercury species seasonal and diurnal variations

$\mathrm{Hg}$ species concentration average and range obtained over the diurnal high-resolution sampling at the two sites are reported in Table A (SM). At the SS, higher concentrations of total mercury $\left(\mathrm{Hg}_{\mathrm{T}}\right)$ and total methylmercury $\left(\mathrm{MMHg}_{\mathrm{T}}\right)$ were observed during the dry season $\left(3.1 \pm 1.7\right.$ and $0.7 \pm 0.2 \mathrm{ng} \mathrm{L}^{-1}$, respectively) than for the wet season $(1.4 \pm 0.3$ and $0.3 \pm$ $\left.0.1 \mathrm{ng} \mathrm{L}^{-1}\right)(\mathrm{p}<0.05)$. This is consistent with the difference observed for conductivity and other metallic cations (data not shown), likely reflecting a concentration effect resulting from the enhanced evaporation at the end of the dry season. At the $\mathrm{NS}$, the concentrations of total mercury $\left(\mathrm{Hg}_{\mathrm{T}}\right)$ (4.6$\left.7.0 \mathrm{ng} \mathrm{L}{ }^{-1}\right)$ and total methylmercury $\left(\mathrm{MMHg}_{\mathrm{T}}\right)(2.0-$ $\left.4.5 \mathrm{ng} \mathrm{L}^{-1}\right)$ were significantly higher $(\mathrm{p}<0.05)$ than at the $\mathrm{SS}$ for the two seasons. Interestingly, the relative proportion of dissolved $\mathrm{MMHg}\left(\mathrm{MMHg}_{\mathrm{d}}\right)$ was found extremely high, representing between $57 \pm 5$ and $23 \pm 9 \%$ at SS during the dry and wet season, respectively, with a maximum value of $64 \pm 8 \%$ at NS during the wet season. This high-dissolved $\mathrm{MMHg}$ partition is probably the highest ever reported in high-altitude lake ecosystems, compared to the southern oligotrophic Moreno Lake (Patagonia, atl 768 m, 0.4 to $2.4 \%$, Arcagni et al. 2013) or in the hypereutrophic contaminated Dianchi Lake (Tibet, $1881 \mathrm{~m}, 0.2-1.5 \%$, Wang et al. 2012). Concentrations of total dissolved mercury $\left(\mathrm{Hg}_{\mathrm{Td}}\right)$ at the SS site were $0.6 \pm 0.1 \mathrm{ng} \mathrm{L}^{-1}$ in the dry season and $1.3 \pm$ $0.8 \mathrm{ng} \mathrm{L}^{-1}$ during the wet season, although higher values were measured at the NS site $3.8 \pm 0.8 \mathrm{ng} \mathrm{L}^{-1}$ for the same season. Overall, $\mathrm{Hg}_{\mathrm{Td}}$ values in Lake Uru Uru are similar to measurements in Moreno Lake (1-5 ng L ${ }^{-1}$, Arcagni et al. 2013) or in waters from Andean glaciers (2.2 to $2.6 \mathrm{ng} \mathrm{L}^{-1}$, MauriceBourgoin et al. 2000), with the relative proportion of $\mathrm{MMHg}$ being significantly higher.

DGM concentrations were mainly composed by 97.0 to $99.9 \%$ of $\mathrm{Hg}^{\circ}$ with only 0-3 \% DMHg. DGM accounted for 0 to $15 \%$ of $\mathrm{Hg}_{\mathrm{Td}}$. DGM concentrations (as $\mathrm{Hg}^{\circ}$ ) at the SS averaged $16.8 \pm 11.7 \mathrm{pg} \mathrm{L}^{-1}$ during the dry season and 49.7 $\pm 43.8 \mathrm{pg} \mathrm{L}^{-1}$ during the wet season, whereas the NS exhibits concentrations averaging $39.8 \pm 14.3 \mathrm{pg} \mathrm{L}^{-1}$ in the wet season. The $\mathrm{Hg}^{\circ}$ concentrations in Lake Uru Uru (3.3-124.7 pg L ${ }^{-1}$ ) are in the same range as those documented for Alaskan lakes (20.0-46.1 pg L ${ }^{-1}$ ) (Tseng et al. 2004) or Canadian lakes (32.1-58.2 $\mathrm{pg} \mathrm{L}^{-1}$ ) (Amyot et al. 1997). Levels of DMHg $(<\mathrm{LD}=0.04-1.64)$ are rather low if compared with published
Table 1 Inorganic mercury methylation, methylmercury demethylation, inorganic mercury reduction, and mercury net methylation (mean $\pm \mathrm{SD}, \mathrm{n}=3$ ) estimates in the water column of the
Lake Uru Uru, under dark and diurnal conditions, during late dry and wet seasons (October 2010 and May 2011) at both southern and northern sites

\begin{tabular}{|c|c|c|c|c|c|c|c|c|c|}
\hline \multirow[t]{2}{*}{ Matrix } & \multirow[t]{2}{*}{ Station } & \multirow[t]{2}{*}{ Season } & \multicolumn{2}{|l|}{ Diurnal } & \multicolumn{2}{|l|}{ Dark } & \multirow{2}{*}{$\begin{array}{l}\text { Diurnal } \\
\mathrm{R} \\
\% \text { day }^{-1}\end{array}$} & \multirow{2}{*}{$\begin{array}{l}\text { Diurnal } \\
\text { Net methylation } \\
\text { ng L }^{-1} \text { day }^{-1}\end{array}$} & \multirow{2}{*}{$\begin{array}{l}\text { Dark } \\
\text { Net methylation } \\
\text { ng L }{ }^{-1} \text { day }^{-1}\end{array}$} \\
\hline & & & $\begin{array}{l}\mathrm{M} \\
\% \text { day }^{-1}\end{array}$ & $\begin{array}{l}\text { D } \\
\% \text { day }^{-1}\end{array}$ & $\begin{array}{l}\mathrm{M} \\
\% \text { day }^{-1}\end{array}$ & $\begin{array}{l}\text { D } \\
\% \text { day }^{-1}\end{array}$ & & & \\
\hline \multirow[t]{4}{*}{ Surface water } & \multirow[t]{2}{*}{ NS } & Dry & $4.9 \pm 0.8$ & $21.0 \pm 1.8$ & $7.7 \pm 1.7$ & $20.5 \pm 1.4$ & $0.6 \pm 0.2$ & $0.20 \pm 0.30$ & $0.45 \pm 0.48$ \\
\hline & & Wet & $0.6 \pm 0.4$ & $6.0 \pm 2.5$ & $0.7 \pm 0.1$ & $3.7 \pm 3.9$ & $0.3 \pm 0.2$ & $-0.11 \pm 0.08$ & $-0.06 \pm 0.10$ \\
\hline & \multirow[t]{2}{*}{ SS } & Dry & $1.0 \pm 1.0$ & $6.7 \pm 1.2$ & $0.9 \pm 0.8$ & $4.0 \pm 1.9$ & $1.0 \pm 0.2$ & $-0.01 \pm 0.04$ & $0.00 \pm 0.03$ \\
\hline & & Wet & $0.04 \pm 0.02$ & $0.4 \pm 0.6$ & $<\mathrm{LD}$ & $0.2 \pm 0.3$ & $0.1 \pm 0.1$ & $-0.00 \pm 0.00$ & $-0.00 \pm 0.00$ \\
\hline \multirow{4}{*}{$\begin{array}{l}\text { Filtered surface } \\
\quad \text { water }\end{array}$} & \multirow[t]{2}{*}{ NS } & Dry & $1.0 \pm 0.9$ & $0.8 \pm 1.2$ & $0.6 \pm 0.2$ & $0.02 \pm 0.23$ & & $0.01 \pm 0.04$ & $0.01 \pm 0.00$ \\
\hline & & Wet & $0.7 \pm 0.4$ & $4.3 \pm 1.2$ & $0.7 \pm 1.5$ & $3.0 \pm 2.7$ & & $-0.06 \pm 0.08$ & $-0.03 \pm 0.16$ \\
\hline & \multirow[t]{2}{*}{ SS } & Dry & $<\mathrm{LD}$ & $<\mathrm{LD}$ & $0.7 \pm 0.9$ & $<\mathrm{LD}$ & & $0.00 \pm 0.00$ & $0.02 \pm 0.02$ \\
\hline & & Wet & $<\mathrm{LD}$ & $<\mathrm{LD}$ & $0.1 \pm 0.1$ & $2.0 \pm 0.4$ & & $-0.01 \pm 0.00$ & $0.00 \pm 0.00$ \\
\hline
\end{tabular}

Limit of detection of the $\mathrm{M}$ and $\mathrm{D}$ method: $\mathrm{LD}=0.02 \% \mathrm{day}^{-1}$

M mercury methylation, D methylmercury demethylation, R inorganic mercury reduction, SS southern, NS northern 
marine studies in the Mediterranean Sea (4-84 $\mathrm{pg} \mathrm{L}^{-1}$ ) (Monperrus et al. 2007) or in the Artic Ocean (7.9 \pm $4.4 \mathrm{pg} \mathrm{L}^{-1}$ ) (Kirk et al. 2008).

The diurnal concentrations of $\mathrm{MMHg}_{\mathrm{T}}$ during the wet season decreased from sunrise $(\sim 6 \mathrm{~h})$ to sunset $(\sim 18 \mathrm{~h})$ and increased overnight until sunrise (Figs. $2 \mathrm{c}$ and $3 \mathrm{~b}$ ). The concentration of $\mathrm{Hg}^{\circ}$ in SS and NS (Fig. 2h) increased from $06 \mathrm{~h}$, with a peak between 12 and $15 \mathrm{~h}$ to further decrease until sunset. The same behavior was also observed for $\mathrm{Hg}^{\circ}$ and DMHg in NS during the wet season (Fig. 3d).

Between both seasons, total MMHg and IHg exhibit different trends at SS that might be related to the occurrence of higher particle contents (and aggregates) during the dry season in the water column. MMHg showed a decreasing trend with increasing oxygen at the SS site during the dry season and at the NS for the wet season $\left(\mathrm{r}^{2}=0.8, \mathrm{p}<0.002\right.$ and $\mathrm{r}^{2}=0.8$, $\mathrm{p}<0.05$, respectively) but no trend for SS during the wet season ( $p>0.05$ ) (Figure A.a,b in SM). This result suggests that $\mathrm{MMHg}$ net accumulation in the water column is likely enhanced when lower oxygen concentrations occur, especially at night when oxygen consumption processes are dominant. Besides MMHg has been reported to be produced within the anoxic layer of lake waters (Eckley and Hintelmann 2006), no anoxia has been observed in this study. This may suggests that more reductive conditions in the water column likely associated to organic matter mineralization can promote $\mathrm{Hg}$ methylation as previously observed (Bouchet et al. 2013; Monperrus et al. 2007). The occurrence of anaerobic bacteria communities in the water column located into anoxic microenvironments (e.g., particles) playing a role in $\mathrm{Hg}$ methylation, such as SRB, has been shown in this study and also previously established in other aquatic systems (Acha et al. 2012). During daytime, water in Lake Uru Uru exhibited oxygen supersaturation, demonstrating intense primary productivity when MMHg levels are decreasing. Such photosynthetic activity may inhibit $\mathrm{Hg}$ methylation triggered under more reductive conditions. Also, this may be due to increased activity of filamentous algae Oedogonium sp. and other algae that have been found to accumulate MMHg (Lanza et al. 2015). The explanation of such decline in MMHg concentrations may also be associated to stronger light-induced demethylation (Black et al. 2012; Lehnherr and St. Louis 2009). As shown in Fig. 2b-d, lower MMHg concentrations coincide with daylight maxima, which mean that solar radiation may influence decline of $\mathrm{MMHg}$. However, the in situ incubations described later (BBiogeochemical transformation of mercury

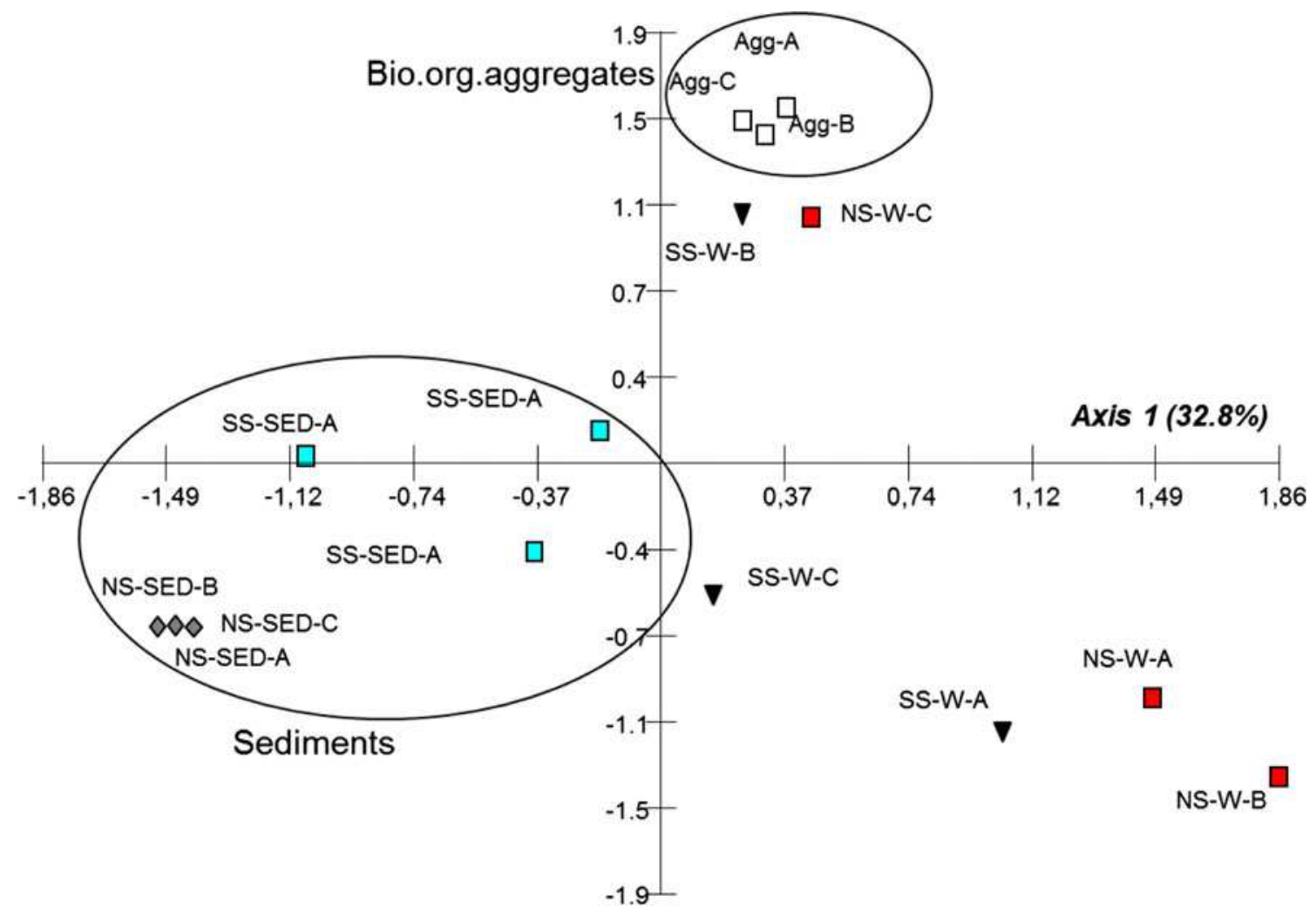

Axis 2 (30.4\%)

Fig. 4 Correspondence analysis based on T-RFLP results for the dsr AB genes in the samples collected during the late dry season at stations SS and NS and in different compartments (W water, Sed sediments, Agg floating bio-organic aggregates). The letters $\mathrm{A}, \mathrm{B}$, and $\mathrm{C}$ refer to triplicates for each sample 
species in water^ section) have shown that light-induced pathways might not be so significant in these waters, since high DOM contents can play an important inhibition effect for UV light-induced demethylation pathways (Black et al. 2012). The behavior of volatile $\mathrm{Hg}$ species also obeys diurnal changes (Figs. $2 \mathrm{~g}$, $\mathrm{h}$ and $3 \mathrm{~d}$ ); $\mathrm{Hg}^{\circ}$ formation processes may be induced by solar radiation (Amyot et al. 1997). Low concentrations of $\mathrm{Hg}^{\circ}$ can be attributed to high-DOC concentrations, which decrease the availability of UV-B radiation to reduce IHg (Amyot et al. 1997). We can also observe (Figs. 2c-h and $3 \mathrm{~b}-\mathrm{d})$ that a small fraction of decreasing MMHg might be converted to DMHg (Monperrus et al. 2007). Overall, we have shown that MMHg and IHg in both dissolved and particulate (or total) phases can exhibit strong diurnal variations which are controlled by various biotic and abiotic processes difficult to be constrained for each season and site. Several pathways such as methylation, demethylation, or reduction of $\mathrm{Hg}$ species in water are able to contribute to these variations (see below BBiogeochemical transformation of mercury species in water $\wedge$ section), while the dynamic exchange with other compartments such as surface sediments and Totora's substrates (see BMercury methylation and demethylation in surface sediments $\wedge^{\wedge}$ and BMethylation and Demethylation in Bioorganic substrates ${ }^{\wedge}$ sections) might involve other sources and sinks for the water column.

Biogeochemical transformation of mercury species in water

Methylation M potentials obtained in unfiltered water samples from Lake Uru Uru ranged between $<0.02$ and $4.9 \%$ day $^{-1}$. Under light conditions, M potentials obtained from unfiltered water samples varied with seasonal changes at both sites (see Table 1, Fig. 5), with higher methylation during the dry season ( $\mathrm{p}<0.05$, Kruskal-Wallis test). M potentials were $4.9 \pm 0.6$ and $0.6 \pm 0.4 \%$ day $^{-1}$ at the NS and $1.0 \pm$ 0.9 and $0.04 \pm 0.02 \%$ day $^{-1}$, at the SS, during the dry and wet seasons, respectively. Dark condition incubations exhibited $\mathrm{M}$ potential between $0.7 \pm 0.1$ and $7.7 \pm 1.7 \%$ day $^{-1}$, for the dry and wet seasons, respectively, at the NS site, although no differences were found at the SS site among seasons $(0.9 \pm$ 0.8 and $<0.02 \%$ day $^{-1}$ ).

For filtered water, $M$ potentials, obtained from light and dark incubations, were lower than $\mathrm{M}$ potential measures in unfiltered water $(\mathrm{p}<0.05)$. While $\mathrm{M}$ potentials obtained at NS site under light and dark conditions were still significant, those obtained at SS site were below the detection limit $\left(<\mathrm{LD}=0.02 \% \mathrm{day}^{-1}\right)$ under light conditions and rather limited $\mathrm{M}$ potentials in dark condition (Table 1). This finding corroborates the observation made on the variations of $\mathrm{MMHg}$ concentrations during the $24-\mathrm{h}$ cycles. This also confirms that $\mathrm{Hg}$ methylation is probably mediated by micro-organisms and organic matter in the absence of sunlight and may also benefit from higher temperatures in the dry season. SRB were detected in all matrices, but the structure of the community was highly variable and specific to the matrix incubated (water, sediments, floating organic aggregates) (Fig. 4).

Comparison to literature values (Table 3 ) shows that the maximum $\mathrm{M}$ potential obtained under light condition (NS, $4.9 \%$ day $^{-1}$ ) is significantly higher than the maximum values obtained in the Arcachon Bay $\left(0.8 \%\right.$ day $^{-1}$, Bouchet et al. 2013) or in estuarine and coastal waters $\left(0.4 \%\right.$ day $^{-1}$; Sharif et al. 2014). However, these significant $M$ potential values remain in the range of $\mathrm{M}$ potential rates determined in the anoxic waters of Canadian lakes $\left(0.6-14.8 \%\right.$ day $^{-1}$, Eckley and Hintelmann 2006), in oxic waters from the Mediterranean $\left(0.3-6.3 \%\right.$ day $^{-1}$ ) (Monperrus et al. 2007) and in Moreno
Table 2 Inorganic mercury methylation, methylmercury demethylation, and mercury net methylation $($ mean $\pm S D, n=3$ ) estimates in surface sediments and bio-organic substrates (aggregates and periphyton) in the Lake Uru Uru, under dark and diurnal conditions, during late dry and wet seasons (October 2010 and May 2011) at both southern and northern sites and Lake Titicaca and Popoo (sediments only)

\begin{tabular}{|c|c|c|c|c|c|c|c|c|}
\hline \multirow[t]{2}{*}{ Matrix } & \multirow[t]{2}{*}{ Station } & \multirow[t]{2}{*}{ Season } & \multicolumn{2}{|l|}{ Diurnal } & \multicolumn{2}{|l|}{ Dark } & \multirow{2}{*}{$\begin{array}{l}\text { Diurnal } \\
\text { Net methylation } \\
\text { ng g }^{-1} \text { day }^{-1}\end{array}$} & \multirow{2}{*}{$\begin{array}{l}\text { Dark } \\
\text { Net methylation } \\
\operatorname{ng~g}^{-1} \text { day }^{-1}\end{array}$} \\
\hline & & & $\begin{array}{l}\text { M } \\
\% \text { day }^{-1}\end{array}$ & $\begin{array}{l}\mathrm{D} \\
\% \text { day }^{-1}\end{array}$ & $\begin{array}{l}\text { M } \\
\% \text { day }^{-1}\end{array}$ & $\begin{array}{l}\mathrm{D} \\
\% \text { day }^{-1}\end{array}$ & & \\
\hline \multirow[t]{6}{*}{ Surface sediment } & \multirow[t]{2}{*}{ NS } & Dry & $1.1 \pm 0.2$ & $68.3 \pm 0.2$ & $5.1 \pm 0.5$ & $27.8 \pm 3.3$ & $3.4 \pm 1.2$ & $19.7 \pm 4.0$ \\
\hline & & Wet & $1.0 \pm 0.1$ & $10.1 \pm 3.2$ & $1.3 \pm 0.2$ & $28.8 \pm 3.6$ & $2.0 \pm 0.5$ & $2.0 \pm 1.0$ \\
\hline & \multirow[t]{2}{*}{ SS } & Dry & $0.25 \pm 0.04$ & $15.6 \pm 1.9$ & $0.35 \pm 0.02$ & $28.0 \pm 1.3$ & $0.5 \pm 0.2$ & $0.6 \pm 0.1$ \\
\hline & & Wet & $0.14 \pm 0.05$ & $9.2 \pm 1.8$ & $0.26 \pm 0.04$ & $5.2 \pm 0.7$ & $0.19 \pm 0.15$ & $0.5 \pm 0.1$ \\
\hline & $\mathrm{TC}$ & Dry & $0.10 \pm 0.00$ & $78.1 \pm 1.9$ & $0.10 \pm 0.01$ & $78.1 \pm 1.7$ & $-0.17 \pm 0.03$ & $-0.17 \pm 0.03$ \\
\hline & PP & Wet & $0.06 \pm 0.02$ & $26.0 \pm 4.0$ & $<\mathrm{LD}$ & $29.1 \pm 1.4$ & $-0.02 \pm 0.03$ & $-0.03 \pm 0.01$ \\
\hline Bio-organic aggregates & SS & Dry & $9.58 \pm 0.05$ & $18.0 \pm 2.4$ & $16.51 \pm 2.8$ & $15.1 \pm 2.6$ & $5.8 \pm 1.8$ & $12.2 \pm 5.1$ \\
\hline Totoras periphyton & NS & Wet & $0.1 \pm 0.0$ & $13.4 \pm 1.3$ & $0.1 \pm 0.0$ & $13.0 \pm 0.4$ & $-2.1 \pm 0.6$ & $-2.1 \pm 0.5$ \\
\hline
\end{tabular}

Limit of detection of the $\mathrm{M}$ and $\mathrm{D}$ method: $\mathrm{LD}=0.1 \% \mathrm{day}^{-1}$

M mercury methylation, D methylmercury demethylation, SS southern, NS northern, TC Lake Titicaca, PP Popoo 
Lake, Argentina $\left(23 \pm 11 \%\right.$ day $\left.^{-1}\right)$ (Ribeiro Guevara et al. 2008).

Demethylation Significant demethylation potentials (D) were measured in surface unfiltered water of Lake Uru Uru ( 0.4 to $21 \%$ day $^{-1}$ ), with almost no significant difference between daylight and in dark conditions (Table 1, Fig. 6). However, D potentials varied seasonally and among sites, being higher in the dry season compared to the wet season $(p<0.05)$ and higher at the NS compared to SS for both season $(\mathrm{p}<0.05)$. At NS, D potentials in dry season were significantly higher $\left(21 \%\right.$ day $\left.^{-1}\right)$ than for the wet season $\left(3.7-6.0 \%\right.$ day $\left.^{-1}\right)$. At SS, D potentials during the dry season were also much higher (4.0-6.7 for dark and light) than during the wet season $(0.2-$ $0.4 \%$ day $\left.^{-1}\right)$. In filtered water, D was either below the detection limit for SS or lower to the values obtained from unfiltered water (except for wet season/dark conditions in SS). These results suggest that demethylation remains a major pathway in waters of Lake Uru Uru, mostly associated to the presence of suspended particulate material and via biotic processes, while direct light-induced photochemical pathways appear to be of a lower importance. As previously observed in various coastal environments (Bouchet et al. 2013; Sharif et al. 2014), biotic-induced demethylation can be a significant pathway to reduce MMHg extent in the water column.

D potentials results for unfiltered water incubation are higher than those measured in the anoxic waters of lakes in Canada $\left(0.12 \%\right.$ day $\left.^{-1}\right)$ (Eckley and Hintelmann 2006), comparable with those measured in a tidal bay by (Bouchet et al. 2013) (6.2-11.9\% day $\left.^{-1}\right)$ but lower compared to those recorded in coastal and marine waters $\left(6.4-24.5 \%\right.$ day $^{-1}$, Monperrus et al. (2007) and 6.6-55.3\% day ${ }^{-1}$, Sharif et al. (2014), respectively) (Table 3).
Reduction The reduction potential (R) in Lake Uru Uru was found of limited intensity and could only be detected during the dry season $\left(0.6-1.0 \%\right.$ day $^{-1}$, Table 1$)$. These low R potentials are consistent with the low $\mathrm{Hg}^{\circ}$ concentrations measured in the lake (Table A). The high content of DOC found in the lake is large enough to potentially inhibit UV and visible light radiations that may induce mercury reduction reactions (Amyot et al. 1997). Further on, $\mathrm{Hg}^{\circ}$ concentrations can also be limited by concomitant photo-oxidation processes catalyzed by organic radicals (Lalonde et al. 2001; Mason et al. 2001).

Net methylation assessment During the dry season, the diurnal net methylation capacity (see SM for details) obtained from unfiltered water samples at NS was $0.20 \pm$ $0.30 \mathrm{ng} \mathrm{L}^{-1}$ day $^{-1}$ under light conditions, compared to 0.45 $\pm 0.48 \mathrm{ng} \mathrm{L}^{-1}$ day $^{-1}$ in dark conditions. During the wet season, the net methylation capacity exhibits a loss of $\mathrm{MMHg}$ within the same range under light $\left(-0.11 \pm 0.08 \mathrm{ng} \mathrm{L}^{-1} \mathrm{day}^{-1}\right)$ and dark conditions $\left(-0.06 \pm 0.10 \mathrm{ng} \mathrm{L}^{-1}\right.$ day $\left.^{-1}\right)$, while this was rather limited when compared to the dry season. At the SS site, net MMHg production for both seasons was found insignificant for both dark and diurnal conditions (Table 1). The rather limited net $\mathrm{MMHg}$ production observed in the water column of the lake contrasts with the high MMHg concentrations determined in this compartment (Figs. 2 and 3; Table A). This suggests that $\mathrm{MMHg}$ present in the water column likely originates from another source. The comparison between the extent of the diurnal variation of $\mathrm{MMHg}$ concentrations in water with the net $\mathrm{M}$ potentials integrated for the same compartment during the same period of time $(24 \mathrm{~h})$ (details in SM, Table C) shows that the high accumulation of MMHg measured in water reflects mainly $\mathrm{MMHg}$ released from sediment
Fig. 5 Diurnal methylation potentials of $\mathrm{Hg}$ determined in the different compartments (bulk and filtered water, sediments, bioorganic substrates) at station SS and NS of Lake Uru Uru for the dry (solid bars) and wet (striped bars)

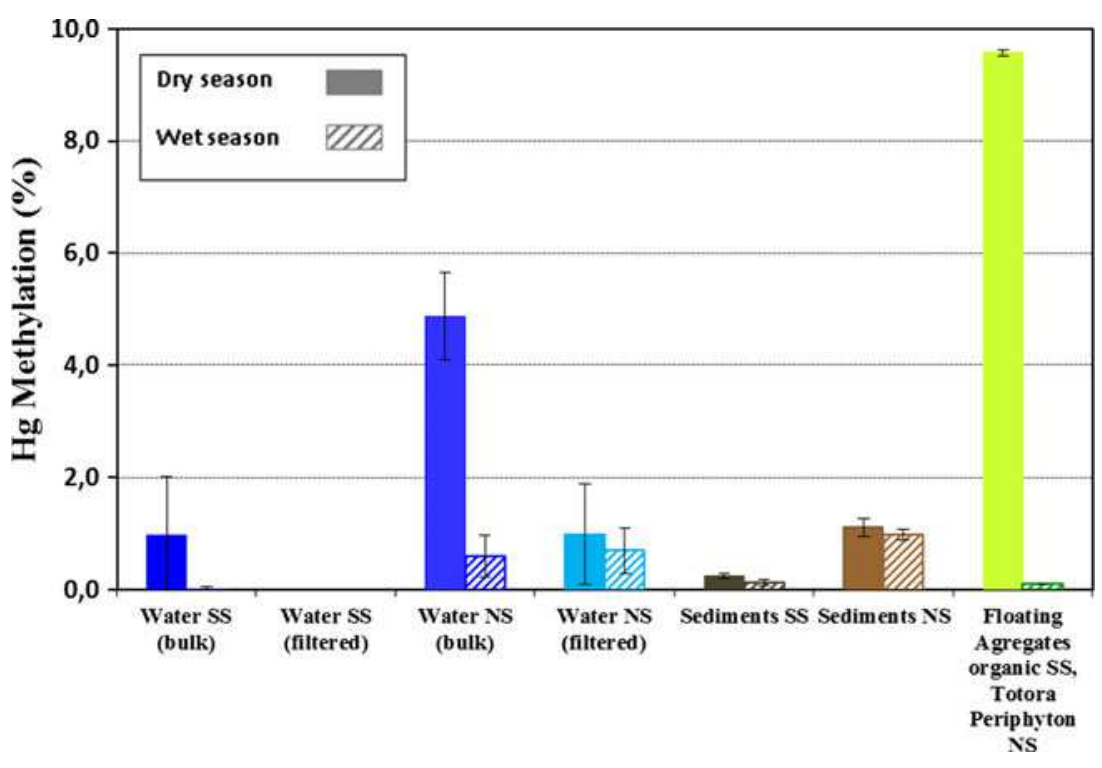


Table 3 Comparison of potential methylation of inorganic mercury and demethylation of methylmercury obtained in water, sediment, and bio-organic substrates (e.g., macrophytic and rhizospheric periphyton, or aggregated biofilms) of Lake Uru Uru with values obtained from incubations in different regions and ecosystems

\begin{tabular}{|c|c|c|c|c|c|c|}
\hline Matrix & Location-ecosystem & Tracers and method & $\begin{array}{l}\text { Incubation } \\
\text { time (day) }\end{array}$ & $\begin{array}{l}\text { Diurnal methylation } \\
\text { yields }\left(\% \text { day }^{-1}\right)\end{array}$ & $\begin{array}{l}\text { Diurnal demethylation } \\
\text { yields }\left(\% \text { day }^{-1}\right)\end{array}$ & Reference \\
\hline \multirow[t]{6}{*}{ Waters } & Mediterranean Sea (marine surface water) & ${ }_{\mathrm{Me}^{201}}^{199} \mathrm{Hg}$ & 1 & $0.3-6.3$ & $6.4-24.5$ & Monperrus et al. (2007) \\
\hline & $\begin{array}{l}\text { Canada, Lakes } \\
\text { (oxycline, water column) }\end{array}$ & ${ }_{\mathrm{Me}^{190} \mathrm{Hg}} \mathrm{Hg}$ & 1 & $0.6-14.8$ & 0.12 & Eckley and Hintelmann (2006) \\
\hline & $\begin{array}{l}\text { France, Arcachon Bay } \\
\text { (1 m depth, water column) }\end{array}$ & ${ }_{\mathrm{Me}^{109} \mathrm{Hg}} \mathrm{Hg}$ & 1 & $\leq 0.02-0.8$ & $6.2-11.9$ & Bouchet et al. (2013) \\
\hline & $\begin{array}{l}\text { Argentina-Moreno lake } \\
\text { (water with plankton }<50 \mu \mathrm{m} \& \\
\text { UV-PA radiation) }\end{array}$ & ${ }^{197} \mathrm{Hg}$ & 1 & $23 \pm 11$ & - & Ribeiro Guevara et al. (2008) \\
\hline & $\begin{array}{l}\text { France, Adour River estuary (Bay } \\
\text { of Biscay, SW) } \\
\text { (coastal surface water) }\end{array}$ & ${ }_{\mathrm{Me}^{199} \mathrm{Hg}} \mathrm{Hg}$ & 1 & $<0.01-0.4$ & $6.6-55.3$ & Sharif et al. (2014) \\
\hline & $\begin{array}{l}\text { Bolivia, Altiplano } \\
\text { Lake Uru Uru } \\
\text { (water column) }\end{array}$ & ${ }_{\mathrm{Me}^{199}}^{{ }^{201}} \mathrm{Hg}$ & 1 & $0.04-4.9$ & $0.4-21.0$ & Present study \\
\hline \multirow[t]{5}{*}{ Sediments } & Brazil, Amazonian Lakes & ${ }^{203} \mathrm{Hg}$ & & $0.022-0.41$ & - & Guimarães et al. $(1994,1999)$ \\
\hline & Brazil, Pantanal Lake & ${ }^{203} \mathrm{Hg}$ & 3 & 1.2 & - & Guimarães et al. (1998) \\
\hline & $\begin{array}{l}\text { Brazil, Sao Paulo } \\
\text { L. do Diogo Lake }\end{array}$ & ${ }^{203} \mathrm{Hg}$ & $2-5$ & 2.5 & & Lemos et al. (1999) \\
\hline & $\begin{array}{l}\text { France, Arcachon Bay } \\
\text { (surface sediment) }\end{array}$ & $\begin{array}{l}{ }^{199} \mathrm{Hg} \\
\mathrm{Me}^{201} \mathrm{Hg}\end{array}$ & 1 & $0.4-3.2$ & $47-72$ & Bouchet et al. (2013) \\
\hline & $\begin{array}{l}\text { Bolivia, Altiplano, } \\
\text { Lake Uru Uru } \\
\text { (surface sediment) }\end{array}$ & ${ }^{199} \mathrm{Hg} \mathrm{Me}{ }^{201} \mathrm{Hg}$ & 1 & $0.14-1.1$ & $9.2-68.3$ & Present study \\
\hline Floating macrophytes & $\begin{array}{l}\text { Brazil, Pantanal } \\
\text { Ipiranga Lake }\end{array}$ & ${ }^{203} \mathrm{Hg}$ & 3 & $2.2-3.5$ & & Guimarães et al. (1998) \\
\hline Phytoplankton & Brazil, Ribeirao das Lajes Reservoir & ${ }^{203} \mathrm{Hg}$ & 4 & 1.5 & & Coelho-Souza et al (2006) \\
\hline Periphyton macrophytes-associated & $\begin{array}{l}\text { Brazil, eutrophic tropical } \\
\text { Lagoinha Lake }\end{array}$ & ${ }^{203} \mathrm{Hg}$ & $4-12$ & $17 / 1.5-7.7$ & & Mauro et al. (2002) \\
\hline \multirow[t]{4}{*}{$\begin{array}{l}\text { Periphyton } \\
\text { roots-associated }\end{array}$} & $\begin{array}{l}\text { Bolivia, Amazon } \\
\text { La Granja Lake }\end{array}$ & $\begin{array}{l}{ }^{200} \mathrm{Hg} \\
{ }^{203} \mathrm{Hg}\end{array}$ & 1 & $27.5-42.7$ & & $\begin{array}{l}\text { Acha et al. (2005); Correia } \\
\text { et al. (2012) }\end{array}$ \\
\hline & $\begin{array}{l}\text { Bolivia, Amazon } \\
\text { Viejo River Lake }\end{array}$ & ${ }^{203} \mathrm{Hg}$ & 1 & $3.1-4.4$ & & Correia et al. (2012) \\
\hline & Bolivia, Amazon, Salinas Lake & ${ }^{203} \mathrm{Hg}$ & 1 & $0.19-0.21$ & & \\
\hline & $\begin{array}{l}\text { France, SW } \\
\text { Sanguinet Lake } \\
\text { France, SW } \\
\text { Aureilhan Lake }\end{array}$ & $\begin{array}{l}{ }^{199} \mathrm{Hg} \\
\mathrm{Me}^{201} \mathrm{Hg} \\
{ }^{199} \mathrm{Hg} \\
\mathrm{Me}^{201} \mathrm{Hg}\end{array}$ & 1 & $\begin{array}{l}6.0 \pm 2.3 \\
4.7 \pm 3.7\end{array}$ & & Gentès et al. (2013) \\
\hline Totoras Periphyton & $\begin{array}{l}\text { Bolivia, Altiplano, } \\
\text { Lake Uru Uru }\end{array}$ & $\begin{array}{l}{ }^{199} \mathrm{Hg} \\
\mathrm{Me}^{201} \mathrm{Hg}\end{array}$ & 1 & 0 & & Present study \\
\hline
\end{tabular}


or bio-organic substrates as previously suggested in other ecosystems (Table 3, Bouchet et al. 2013; Guimaraes et al. 1999; Guimarães et al. 2000; Point et al. 2007).

Mercury methylation and demethylation in surface sediments

MMHg concentrations in sediments from Lake Uru Uru were found to range from $0.9 \pm 0.2$ to $4.0 \pm 1.3 \mathrm{ng} \mathrm{g}^{-1}$ and those of IHg from $200 \pm 12$ to $394 \pm 35 \mathrm{ng} \mathrm{g}^{-1}$, with the highest values being observed at the NS site (Table B). Also, the percentages of organic carbon $(\sim 5.8 \%)$ and sulfur $(\sim 1 \%)$ were similar in magnitude at both sites. Concentrations of $\mathrm{MMHg}$ and $\mathrm{IHg}$ in sediments from Lakes Titicaca and Poopó were very low in comparison to those in Lake Uru Uru (Table B).

Methylation Overall, diurnal M rates in Lake Uru Uru sediments ranged from $0.14 \pm 0.05$ to $1.1 \pm 0.2 \%$ day $^{-1}$ (Table 2, Fig. 5). Higher $\mathrm{M}$ values were found at NS (1.0-1.1 \% day ${ }^{-1}$ ) than for SS $\left(0.14-0.25 \%\right.$ day $\left.^{-1}\right)$ for both seasons ( $\left.p<0.05\right)$. M potentials remained significantly higher in dark conditions at both sites and for both seasons. Complementary data obtained from nearby Lake Titicaca and lake Poopó showed similar ( $p>0.05$ ) but low M potentials (give values here), in the same range as those measured at SS for the same season (Table 2). These data probably reflect a baseline value for $\mathrm{Hg}$ methylation in undisturbed sediment of the TDPS watershed. The diurnal M potential in the sediments of Lake Uru Uru are also comparable with other lacustrine or coastal sites previously investigated under similar experimental conditions (Table 3).

Demethylation Demethylation potentials in Lake Uru Uru sediments during the dry season, under daylight conditions, were significantly different between NS and SS sites
( $\mathrm{p}<0.05$ ), exhibiting $68.3 \pm 0.2$ and $15.6 \pm 1.9 \%$ day $^{-1}$, respectively (Table 2, Fig. 6). Under dark conditions, the D potentials were similar $\left(28 \pm 3\right.$ and $28 \pm 1 \%$ day $\left.^{-1}\right)$ at both sites. In the wet season, the D potentials were significantly lower for both NS and SS (respectively, 10.1 \pm 3.2 and 9.2 $\pm 1.8 \%$ day $^{-1}$, $\mathrm{p}<0.05)$. While under dark condition, the $\mathrm{D}$ potentials were $29 \pm 4 \%$ day $^{-1}$ for the NS and $5.2 \pm 0.7 \%$ day $^{-1}$ for SS.

In Lake Poopó, D values were similar under daylight and darkness conditions (26.0-29.1\% day ${ }^{-1}$, Table 2) ( $\left.\mathrm{p}>0.05\right)$, while much higher D potentials were measured in Lake Titicaca (ca. $78 \%$ day $^{-1}$ ). In all sediment types from the different lakes of this Altiplano region, D always remains a significant process, as previously shown in sediments from other locations (Table 3). Degradation of MMHg in sediments of Lake Uru Uru cannot be clearly attributed to either lightinduced or dark processes, but likely involving more specifically different bacteria communities and assemblages. For instance, a study carried out by Oremland et al. (1991) in anoxic sediments found that communities of metallogenic and sulfate-reducing bacteria are involved in $\mathrm{MMHg}$ demethylation processes. Bouchet et al. (2013) also found significant demethylation rates in a shallow coastal lagoon under similar experimental conditions (Table 3 ) which was clearly not enhanced under light exposition.

Net methylation assessment The net M calculations (Table 2) indicate that the methylation capacity of sediments was much higher relative to the water compartment and leading to higher yield during the dry season. The comparison of the two sites shows that MMHg was mainly produced in the sediment at NS, for both seasons $\left(3.4 \pm 1.2\right.$ and $2.0 \pm 0.5 \mathrm{ng} \mathrm{g}^{-1}$ day $^{-1}$ for the dry and wet seasons, respectively). Although net methylation rates at SS were lower than those at NS, they remained slightly positive $\left(0.5 \pm 0.2\right.$ and $0.19 \pm 0.15 \mathrm{ng} \mathrm{g}^{-1}$ day $^{-1}$ for the
Fig. 6 Diurnal demethylation potentials of $\mathrm{Hg}$ determined in the different compartments (bulk and filtered water, sediments, bioorganic substrates) at station SS and NS of Lake Uru Uru for the dry (solid bars) and wet (striped bars) season

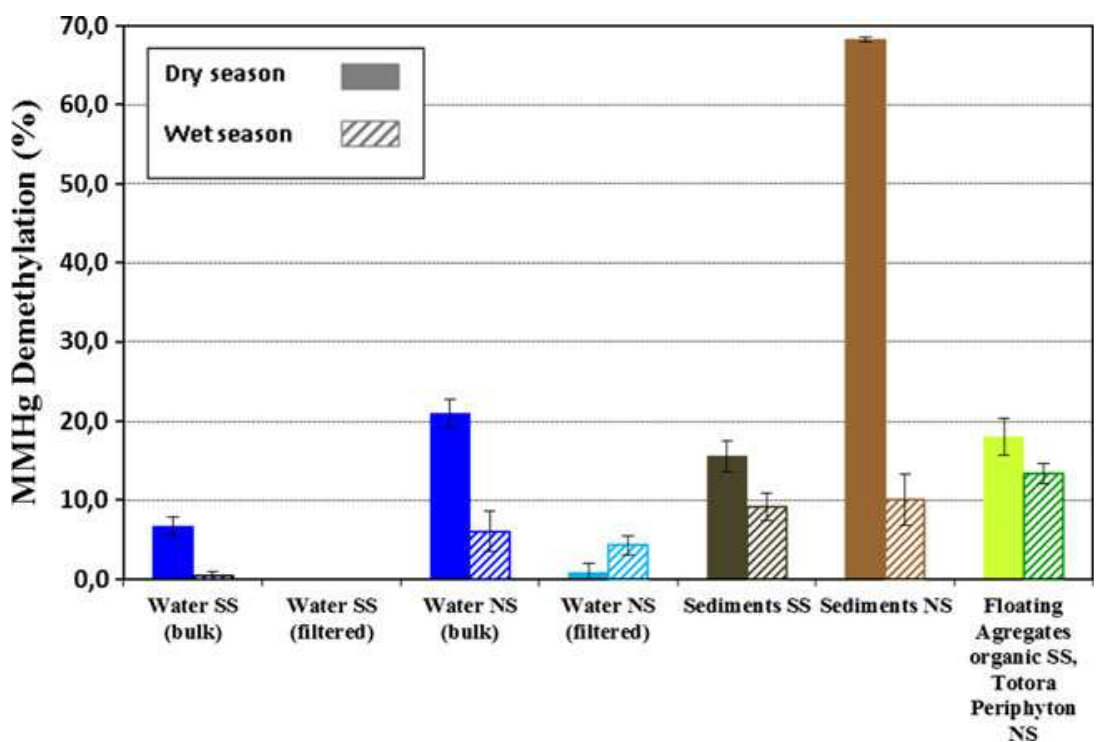


dry and wet seasons, respectively). In contrast, the negative net $\mathrm{M}$ in Lakes Titicaca and Poopó suggest that the sediment may not be a significant source, but a sink of $\mathrm{MMHg}(-0.17 \pm$ 0.03 and $-0.02 \pm 0.03 \mathrm{ng} \mathrm{g}^{-1}$ day $^{-1}$, respectively).

Methylation and demethylation in bio-or ganic substrates

Organic floating aggregates presented higher concentrations of $\mathrm{IHg}\left(86.4 \pm 13.5 \mathrm{ng} \mathrm{g}^{-1}\right)$ than the periphyton associated with the Totora plant $\left(33.5 \pm 2.5 \mathrm{ng} \mathrm{g}^{-1}\right)$ (Table B). Similar concentrations of $\mathrm{MMHg}$ were found in the Totora's periphyton (16.1 \pm $\left.3.2 \mathrm{ng} \mathrm{g}^{-1}\right)$ and in floating organic aggregates $\left(13.5 \pm 0.8 \mathrm{ng} \mathrm{g}^{-1}\right)$.
The $\mathrm{M}$ potential of the floating organic aggregates incubated under sunlight conditions was $9.58 \pm 0.05$ and $16.51 \pm$ $2.8 \%$ day $^{-1}$ under dark conditions (Table 2, Figs. 5 and 6). Diurnal and dark D rates were in a similar range, with $18.0 \pm$ 2.4 and $15.1 \pm 2.6 \%$ day $^{-1}$, respectively. This indicates that in floating organic aggregates, methylation takes place principally by means of dark biotic mechanisms. This process is probably linked to sulfate-reducing bacterial community identified in this matrix, which is also different from other SRB communities found in the waters and sediments of Lake Uru Uru (Fig. 4). The formation of anoxic niches in the organic aggregates may also promote $\mathrm{Hg}$ methylation mediated by
Fig. 7 Schematic representation of the potential net methylation of $\mathrm{Hg}$ occurring in different compartments of Lake Uru Uru for a dry season and $b$ wet season. Net methylation are expressed in nanograms per gram per day in order to compare water, sediment, and bio-organic substrate incubation measurements (a)

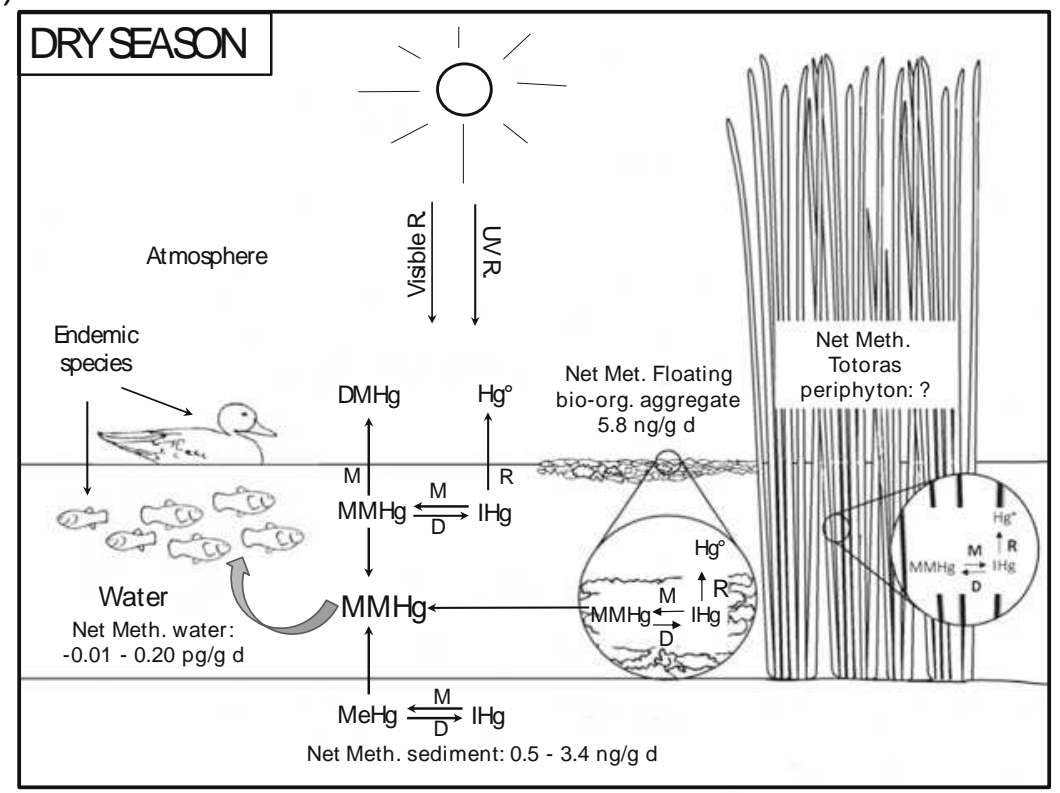

(b)

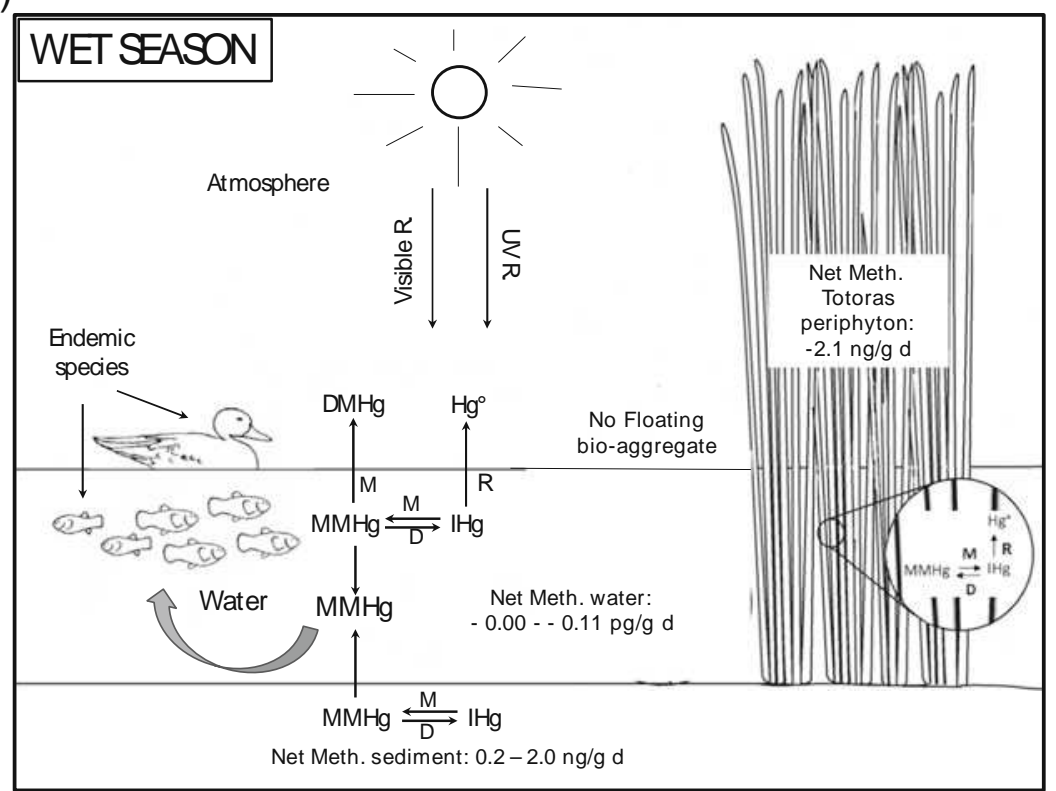


anaerobic communities. In this sense, it should be taken into account that the particulate matter, and more specifically large and small organic aggregates, may be also components contributing to $\mathrm{MMHg}$ burden in the water column as observed during the dry season.

$\mathrm{Hg}$ methylation capacity of the periphyton associated with Totora plants was found negligible $\left(\angle \mathrm{LD}=0.1 \% \mathrm{day}^{-1}\right)$. However, significant D extents were measured (13.4 \pm $1.3 \%$ day $^{-1}$ ), with no difference with the incubation made under darkness (Table 2, Figs. 5 and 6). Conversely, these results show a high $\mathrm{MMHg}$ demethylation capacity involving the participation of diverse aquatic micro-organisms, including bacteria communities. Periphyton associated with Totora's plant tend to accumulate MMHg. Interestingly, Lanza et al. (2015) suggest that algae found in these periphyton, such as Oedogonium sp. can bioconcentrate metals and also $\mathrm{MMHg}$ in Lake Uru Uru showing that periphyton could be beneficial in reducing aqueous $\mathrm{MMHg}$ by both accumulation and degradation.

Net methylation assessment The floating organic aggregates were characterized by a net methylation capacity of $5.8 \pm$ $1.8 \mathrm{ng} \mathrm{g}^{-1} \mathrm{day}^{-1}$, which is twice higher under dark conditions, while Totora's periphyton showed a net demethylation capacity of $2.3 \pm 0.7 \mathrm{ng} \mathrm{g}^{-1}$ day $^{-1}$, with no change in dark conditions (Table 2). MMHg production in periphyton isolated from Totora plants seems very low in comparison to previous experiments with periphyton associated to macrophytes from the Bolivian Amazon (Table 3). Meanwhile, the diurnal methylation potential of floating organic aggregates $(9.58 \pm$ $0.05 \%$ day $^{-1}$ ) was found to be in the same range than the periphyton associated with macrophytes from tropical ecosystems and from other temperate lakes (Table 3 ).

\section{Implications for $\mathrm{MMHg}$ contamination in Lake Uru Uru}

Lake Uru Uru (and part of the TDPS watershed, Bolivian Altiplano) acts as a sink for several mining and urban waste effluents (Garcia 2006; Tapia et al. 2012). Mercury pollution may become an important threat for local population living from hunting and fishing of several endemic species. Potential exposure to elevated $\mathrm{MMHg}$ levels was assessed in various species of water birds and fish from Lake Uru Uru exhibiting $\mathrm{Hg}$ levels averaging around 2 and $1 \mu \mathrm{g} \mathrm{g}^{-1}$ in birds and fish muscle, respectively (Aguirre et al. 2014; Molina et al. 2012). Thus, the elucidation of the main processes controlling the production of $\mathrm{MMHg}$ in the lake is of primary importance and is summarized in Fig. 7. During the dry season, the highest $\mathrm{Hg}$ methylation potential was found in floating organic aggregates, followed by sediments (Fig. 7a). A lower methylation capacity in sediments was found during the wet season
(Fig. 7b). The origin of the floating organic aggregates and their biological composition is not well understood. Their presence was only reported during the dry season and may result from the decomposition and flocculation of fresh organic matter originating from the autotrophic production of plankton, Totora's periphyton exudates, and suspended particulate matter in combination with the higher conductivity reported during this season. The complementary contribution of organic matter originating from the discharge of urban effluents localized in the northern part of Lake Uru Uru has also to be considered. $\mathrm{Hg}$ methylation potentials measured were low in the water column compared to the sediments. This suggests that the increasing $\mathrm{MMHg}$ concentrations measured in the water during the 24-h cycle may also reflect the contribution of $\mathrm{MMHg}$ originating from other aquatic compartments, such as bio-organic substrates during the dry season, but with a constant resupply from the sediment compartment.

Acknowledgments This work is a contribution to the COMIBOL project (INSU CNRS/IRD EC2CO Program) and LAPACHAMAMA project (ANR CESA program, No. ANR-13-CESA-0015-01). We wish to thank J.L. Duprey, A. Castillo, M. Claure (IRD Bolivia), and Don German Calizaya (Fishermen Association, Machacamarca, Bolivia) for their help and assistance during the field campaigns.

\section{References}

Acha D, Hintelmann $\mathrm{H}$, Pabon CA, Iñiguez V, Roulet M, Guimaraes JRD, Luna R, Alanoca L, Sanchez S (2005) Sulfate-reducing bacteria in floating macrophyte rhizosphere from an Amazonian flood plain lake in Bolivia and their association with $\mathrm{Hg}$ methylation. Appl Environ Microbiol 71(11):7531-7535

Acha D, Pabon CA, Hintelmann H (2012) Mercury methylation and hydrogen sulfide production among unexpected strains isolated from periphyton of two macrophytes of the Amazon. FEMS Microbiol Ecol 80:637-645

Aguirre M, Lazzaro X, Point D, Pouilly M (2014) Línea base de conocimientos sobre los recursos hidrológicos en el sistema TDPS con enfoque en la cuenca del Lago Titicaca. IRD - UICN, Quito, Ecuador, $\mathrm{p} 320$

Allen JW, Shanker G, Tan KH, Aschner M (2002) The consequences of methylmercury exposure on interactive functions between astrocytes and neurons. Neurotoxicology 23:755-759

Amyot MS, Mierle G, Lean D, McQueen DJ (1997) Effect of solar radiation on the formation of dissolved gaseous mercury in temperate lakes. Geochim Cosmochim Acta 61:975-987

Arcagni M, Campbell L, Arribére MA, Marvin-DiPasquale M, Rizzo A, Ribeiro GS (2013) Differential mercury transfer in the aquatic food web of a double basined lake associated with selenium and habitat. Sci Total Environ 454-455:170-180

Baldi F, Parati F, Filippelli M, Electric Power Research Institute PACAUS, Environment C, Atmospheric Environment Service C et al (1995) Dimethylmercury and dimethylmercury-sulfide of microbial origin in the biogeochemical cycle of $\mathrm{Hg}$ (English). In: Mercury as a global pollutant. International conference (English), vol 80. Springer, Dordrecht, pp 805-815

Barkay T, Wagner-Döbler I (2005) Microbial transformations of mercury: potentials, challenges, and achievements in controlling mercury toxicity in the environment. Adv Appl Microbiol 57:1-52 
Black FJ, Poulin BA, Flegal AR (2012) Factors controlling the abiotic photo-degradation of monomethylmercury in surface waters. Geochim Cosmochim Acta 84:492-507

Blumthaler M, Ambach W, Ellinger R (1997) Regular paper: increase in solar UV radiation with altitude. J Photochem Photobiol B Biol 39: 130-134

Bouchet S, Tessier E, Monperrus M, Bridou R, Clavier J, Thouzeau G et al (2011) Measurements of gaseous mercury exchanges at the sediment-water, water-atmosphere and sediment-atmosphere interfaces of a tidal environment (Arcachon Bay, France). J Environ Monit: JEM 13:1351-1359

Bouchet S, Amouroux D, Rodriguez-Gonzalez P, Tessier E, Monperrus M, Thouzeau G et al (2013) MMHg production and export from intertidal sediments to the water column of a tidal lagoon (Arcachon Bay, France). Biogeochemistry 114:341-358

Coelho-Souza SA, Guimarães JRD, Mauro JBN (2006) Mercury methylation and bacterial activity associated to tropical phytoplankton. Sci Total Environ 364:188-199

Compeau G, Bartha R (1984) Methylation and demethylation of mercury under controlled redox, $\mathrm{pH}$ and salinity conditions. Appl Environ Microbiol 48:1203-1207

Correia RRS, Miranda MR, Guimaraes JRD (2012) Mercury methylation and the microbial consortium in periphyton of tropical macrophytes: effect of different inhibitors. Environ Res 112:86-91

Craig PJ, Morton SF (1978) Kinetics and mechanism of the reaction between methylcobalamin and mercuric chloride. J Organomet Chem 145:79-89

Eckley CS, Hintelmann H (2006) Determination of mercury methylation potentials in the water column of lakes across Canada. Sci Total Environ 368:111-125

Fitzgerald WF, Clarkson TW (1991) Mercury and monomethylmercury-present and future concerns. Environ Health Perspect 96:159-166

Fitzgerald WF, Lamborg CH (2004) Geochemistry of mercury in the environment treatise on geochemistry, vol 9. Elsevier, Oxford

Garcia ME (2006) Transport of arsenic and heavy metals to Lake PoopóBolivia Natural Leakage and Antropogenic Effects Department of Water Resource Engineering Lund Institute of Technology. Doctoral Thesis. Lund, Sweden

Gentès S, Monperrus M, Legeay A, Maury-Brachet R, Davail S, André J$\mathrm{M}$ et al (2013) Incidence of invasive macrophytes on methylmercury budget in temperate lakes: central role of bacterial periphytic communities. Environ Pollut 172:116-123

Guimarães JRD, Malm O, Padovani C, Sanches M, Forsberg B, Pfeiffer WC (1994) A summary of data on net mercury methylation rates in sediment, water, soil and other samples from the Amazon region obtained through radiochemical methods. Proceedings of the international workshop on environmental mercury pollution and its health effects in Amazon River Basin, Rio de Janeiro, p 94-99

Guimarães JRD, Meili M, de Souza Brito EM (1998) Hg methylation in sediments and floating meadows of a tropical lake in the Pantanal floodplain, Brazil. Sci Total Environ 213:165-175

Guimaraes JRD, Fostier A-H, Forti MC, Melfi JA, Kehrig H, Mauro JBN et al (1999) Mercury in human environmental samples from two lakes in Amapa, Brazilian Amazon. Ambio 28:296-301

Guimarães JRD, Meili M, Hylander LD, EdCe S, Roulet M, Mauro JBN et al (2000) Mercury net methylation in five tropical flood plain regions of Brazil: high in the root zone of floating macrophyte mats but low in surface sediments and flooded soils. Sci Total Environ 261:99-107

Hammerschmidt CR, Fitzgerald WF (2006) Photodecomposition of methylmercury in an Arctic Alaskan Lake (English). Environ Sci Technol 40:1212-1216

Hintelmann H (2010) Organomercurials. Their formation and pathways in the environment. Met Ions Life Sci 7:365-401
Hollweg TA, Gilmour CC, Mason RP (2009) Methylmercury production in sediments of Chesapeake Bay and the mid-Atlantic continental margin. Mar Chem 114:86-101

Kirk JL, Louis VLS, Hintelmann H, Lehnherr I, Else B, Poissant L (2008) Methylated mercury species in marine waters of the Canadian high and sub arctic (English). Environ Sci Technol 42:8367-8373

Lalonde JD, Amyot M, Kraepiel AML, Morel FMM (2001) Photooxidation of $\mathrm{Hg}(0)$ in artificial and natural waters (English). Environ Sci Technol 35:1367-1372

Lanza WG, Acha D, Point D, Masbou J, Alanoca L, Amouroux D, et al (2015) Association of a specific algal group to methylmercury accumulation in periphyton of a tropical high-altitude Andean Lake. 2015; submitted

Lehnherr I, St. Louis VL (2009) Importance of ultraviolet radiation in the photodemethylation of methylmercury in freshwater ecosystems (English). Environ Sci Technol 43:5692-5698

Lemos RA, Guimarães JRD, Bianchini JI (1999) Mercury methylation in Eichhorniaazurea roots and sediments during a seasonal cycle in a Brazilian lake. Proceedings of the 5th International Conference on $\mathrm{Hg}$ as a Global Pollutant, Rio de Janeiro, Brazil, p 462

Marusczak N, Larose C, Dommergue A, Paquet S, Beaulne J-S, MauryBrachet R et al (2011) Mercury and methylmercury concentrations in high altitude lakes and fish (Arctic charr) from the French Alps related to watershed characteristics. Sci Total Environ 409:19091915

Mason RP, Lawson NM, Sheu GR (2001) Mercury in the Atlantic Ocean: factors controlling air-sea exchange of mercury and its distribution in the upper waters. Deep-Sea Res II Top Stud Oceanogr 48:2829_ 2853

Maurice-Bourgoin L, Quiroga I, Chincheros J, Courau P (2000) Mercury distribution in waters and fishes of the upper Madeira rivers and mercury exposure in riparian Amazonian populations. Sci Total Environ 260:73-86

Mauro JBN, Guimarães JRD, Hintelmann H, Watras CJ, Haack EA, Coelho-Souza SA (2002) Mercury methylation in macrophytes, periphyton, and water-comparative studies with stable and radiomercury additions. Anal Bioanal Chem 374:983-989

Molina CI, Ibañez C, Gibon FM (2012) Proceso de biomagnificación de metales pesados en un lago hiperhalino (Poopó, Oruro, Bolivia): Posible riesgo en la salud de consumidores. Ecología en Bolivia [online] 47:99-118

Monperrus M, Tessier E, Veschambre S, Amouroux D, Donard O (2005) Simultaneous speciation of mercury and butyltin compounds in natural waters and snow by propylation and species-specific isotope dilution mass spectrometry analysis. Anal Bioanal Chem 381:854862

Monperrus M, Tessier E, Amouroux D, Leynaert A, Huonnic P, Donard OFX (2007) Mercury methylation, demethylation and reduction rates in coastal and marine surface waters of the Mediterranean Sea. Mar Chem 107:49-63

Monperrus M, Gonzalez PR, Amouroux D, Garcia Alonso JI, Donard OFX (2008) Evaluating the potential and limitations of doublespiking species-specific isotope dilution analysis for the accurate quantification of mercury species in different environmental matrices. Anal Bioanal Chem 390:655-666

Oremland RS, Culbertson CW, Winfrey MR (1991) Methylmercury decomposition in sediments and bacterial cultures: involvement of methanogens and sulfate reducers in oxidative demethylation (English). Appl Environ Microbiol (Print) 57:130-137

Point D, Monperrus M, Tessier E, Amouroux D, Chauvaud L, Thouzeau $\mathrm{G}$ et al (2007) Biological control of trace metal and organometal benthic fluxes in a eutrophic lagoon (Thau Lagoon, Mediterranean Sea, France). Estuar Coast Shelf Sci 72:457-471

Qianggong Z, Ke P, Shichang K, Aijia Z, Wen-Xiong W (2014) Mercury in wild fish from high-altitude aquatic ecosystems in the Tibetan Plateau. Environ Sci Technol 48:5220-5228 
Ribeiro Guevara S, Queimaliños CP, Diéguez MC, Arribére M (2008) Methylmercury production in the water column of an ultraoligotrophic lake of Northern Patagonia, Argentina. Chemosphere 72:578-585

Rodriguez-Gonzalez P, Bouchet S, Monperrus M, Tessier E, Amouroux D (2013) In situ experiments for element species-specific environmental reactivity of tin and mercury compounds using isotopic tracers and multiple linear regression. Environ Sci Pollut Res Int 20:1269-1280

Schaefer JK, Jane Y, Reinfelder JR, Cardona T, Ellickson KM, Tel-Or S et al (2004) Role of the bacterial organomercury lyase (MerB) in controlling methylmercury accumulation in mercury-contaminated natural waters. Environ Sci Technol 38:4304-4311

Sellers P, Kelly CA, Rudd JWM, MacHutchon AR (1996) Photodegradation of methylmercury in lakes. Nature [London] 380:694-697

Sharif A, Monperrus M, Tessier E, Bouchet S, Pinaly H, RodriguezGonzalez P et al (2014) Fate of mercury species in the coastal plume of the Adour River estuary (Bay of Biscay, SW France). Sci Total Environ 496:701-713

Spangler WJ, Spigarelli JL, Rose JM, Flippin RS, Miller HH (1973) Degradation of methylmercury by bacteria isolated from environmental samples. Appl Microbiol 25:488-493
Tapia J, Audry S, Townley B, Duprey JL (2012) Geochemical background, baseline and origin of contaminants from sediments in the mining-impacted Altiplano and Eastern Cordillera of Oruro, Bolivia. Geochem Explor Environ Anal 12:3-20

Tseng CM, Lamborg C, Fitzgerald WF, Engstrom DR (2004) Cycling of dissolved elemental mercury in Arctic Alaskan lakes. Geochim Cosmochim Acta 68:1173-1184

UNEP (2013) Global mercury assessment 2013: sources, emissions, releases and environmental transport 2013. UNEP Chemicals Branch, Geneva

Wang S, Zhang M, Li B, Xing D, Wang X, Wei C et al (2012) Comparison of mercury speciation and distribution in the water column and sediments between the algal type zone and the macrophytic type zone in a hypereutrophic lake (Dianchi Lake) in southwestern China. Sci Total Environ 417-418:204-213

Weber JH (1993) Review of possible paths for abiotic methylation of mercury(II) in the aquatic environment. Chemosphere 26:20632077

Zaratti F, Forno RN, Garcia Fuentes J, Andrade MF (2003) Erythemally weighted UV variations at two high-altitude locations. J Geophys Res 108:ACH5-ACH1-6 